\section{Pacific Northwest}

National Laboratory

Operated by Battelle for the

U.S. Department of Energy

\title{
Annual Hanford Seismic Report for Fiscal Year 2007
}

Pacific Northwest National Laboratory

Hanford Seismic Assessment Team

A. C. Rohay

M. D. Sweeney

D. C. Hartshorn

R. E. Clayton

J. L. Devary

December 2007

Prepared for the U.S. Department of Energy

under Contract DE-AC05-76RL01830 


\title{
DISCLAIMER
}

This report was prepared as an account of work sponsored by an agency of the United States Government. Neither the United States Government nor any agency thereof, nor Battelle Memorial Institute, nor any of their employees, makes any warranty, express or implied, or assumes any legal liability or responsibility for the accuracy, completeness, or usefulness of any information, apparatus, product, or process disclosed, or represents that its use would not infringe privately owned rights. Reference herein to any specific commercial product, process, or service by trade name, trademark, manufacturer, or otherwise does not necessarily constitute or imply its endorsement, recommendation, or favoring by the United States Government or any agency thereof, or Battelle Memorial Institute. The views and opinions of authors expressed herein do not necessarily state or reflect those of the United States Government or any agency thereof.

\author{
PACIFIC NORTHWEST NATIONAL LABORATORY \\ operated by \\ BATTELLE \\ for the \\ UNITED STATES DEPARTMENT OF ENERGY \\ under Contract DE-AC05-76RL01830 \\ Printed in the United States of America \\ Available to DOE and DOE contractors from the \\ Office of Scientific and Technical Information, \\ P.O. Box 62, Oak Ridge, TN 37831-0062; \\ ph: (865) 576-8401 \\ fax: $(865) 576-5728$ \\ email: reports@adonis.osti.gov

\footnotetext{
Available to the public from the National Technical Information Service, U.S. Department of Commerce, 5285 Port Royal Rd., Springfield, VA 22161 ph: (800) 553-6847 fax: $(703) 605-6900$ email: orders@ntis.fedworld.gov online ordering: http://www.ntis.gov/ordering.htm
} 
PNNL-17183

\title{
Annual Hanford Seismic Report for Fiscal Year 2007
}

\author{
A. C. Rohay \\ M. D. Sweeney \\ D. C. Hartshorn \\ R. E. Clayton \\ J. L. Devary
}

December 2007

Prepared for

the U.S. Department of Energy

under Contract DE-AC05-76RL01830

Pacific Northwest National Laboratory

Richland, Washington 99352 


\section{Summary}

The Hanford Seismic Assessment Program (HSAP) provides an uninterrupted collection of highquality raw and processed seismic data from the Hanford Seismic Network for the U.S. Department of Energy and its contractors. The Hanford Seismic Assessment Team locates and identifies sources of seismic activity and monitors changes in the historical pattern of seismic activity at the Hanford Site. The data are compiled, archived, and published for use by the Hanford Site for waste management, natural phenomena hazards assessments, and engineering design and construction. In addition, the seismic monitoring organization works with the Hanford Site Emergency Services Organization to provide assistance in the event of a significant earthquake on the Hanford Site. The Hanford Seismic Network and the Eastern Washington Regional Network consist of 41 individual sensor sites and 15 radio relay sites maintained by the Hanford Seismic Assessment Team.

During fiscal year 2007, the Hanford Seismic Network recorded 1254 triggers on the seismometer system, which included 134 seismic events in the southeast Washington area and an additional 421 regional and teleseismic events. There were 85 events determined to be local earthquakes relevant to the Hanford Site. The highest-magnitude event $\left(2.3 \mathrm{M}_{\mathrm{c}}\right)$ occurred on March 20, 2007. The earthquake was considered a random event, with epicenter located approximately $20 \mathrm{~km}$ west of Othello, Washington, and focus within the crystalline basement. Stratigraphically, 42 earthquakes were located in the Columbia River Basalt Group (approximately 0-4 km depth), 13 earthquakes were located in the prebasalt sediments (approximately 5-8 km depth), and 30 earthquakes were located in the crystalline basement (approximately 9-25 km depth). Geographically, 52 earthquakes were located within swarm areas, and 32 earthquakes were classified as random events. One earthquake was located near a geologic structure (Saddle Mountain anticline).

The Hanford strong motion accelerometer (SMA) network was triggered once during fiscal year 2007. The 300 Area and the 400 Area SMAs detected the 2.0- $\mathrm{M}_{\mathrm{c}}$ seismic event that occurred on April 16, 2007. The 400 Area SMA recorded a maximum vertical acceleration of $0.25 \% \mathrm{~g}$ and a maximum horizontal acceleration of $0.23 \% \mathrm{~g}$. The reportable action level for Hanford facilities $(2 \% \mathrm{~g})$ is approximately eight times larger than the peak accelerations recorded at the 400 Area, and no action was required. 


\section{Abbreviations and Acronyms}

$\begin{array}{ll}\text { BWIP } & \text { Basalt Waste Isolation Project } \\ \text { CRBG } & \text { Columbia River Basalt Group } \\ \text { DOE } & \text { U.S. Department of Energy } \\ \text { ETNA } & \text { strong motion accelerometer manufactured by Kinemetrics } \\ \text { EWRN } & \text { Eastern Washington Regional Network } \\ \text { FY } & \text { fiscal year } \\ \text { GPRS } & \text { General Packet Radio Service } \\ \text { GPS } & \text { Global Positioning System } \\ \text { HSAP } & \text { Hanford Seismic Assessment Program } \\ \text { HSN } & \text { Hanford Seismic Network } \\ \text { IRIS } & \text { Incorporated Research Institutions for Seismology } \\ \text { LIGO } & \text { Laser Interferometric Gravitational-Wave Observatory } \\ M_{c} & \text { coda-length magnitude } \\ M_{L} & \text { local magnitude } \\ \text { NSF } & \text { National Science Foundation } \\ \text { PNNL } & \text { Pacific Northwest National Laboratory } \\ \text { SMA } & \text { strong motion accelerometer } \\ \text { USGS } & \text { U.S. Geological Survey } \\ \text { UTC } & \text { Coordinated Universal Time } \\ \text { UW } & \text { University of Washington } \\ \text { WHC } & \text { Westinghouse Hanford Company } \\ & \end{array}$




\section{Contents}

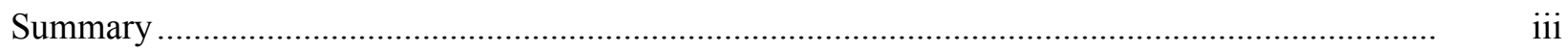

Abbreviations and Acronyms …...................................................................................

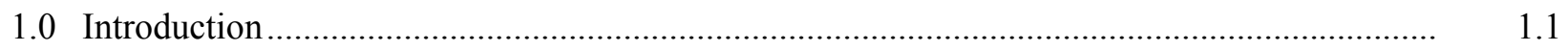

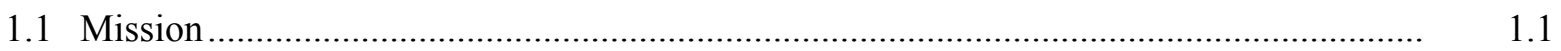

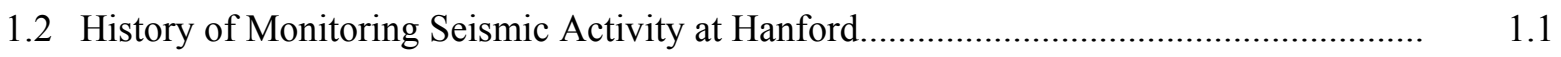

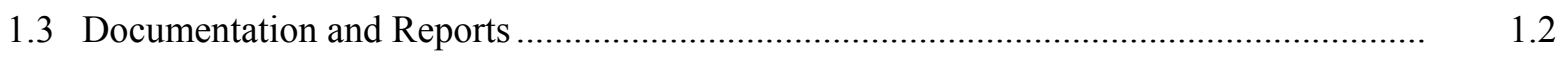

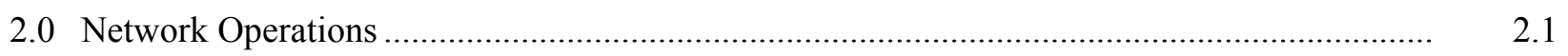

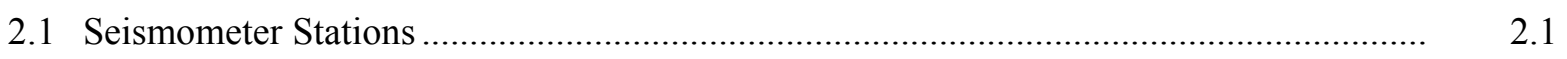

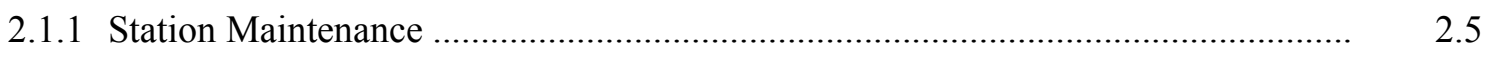

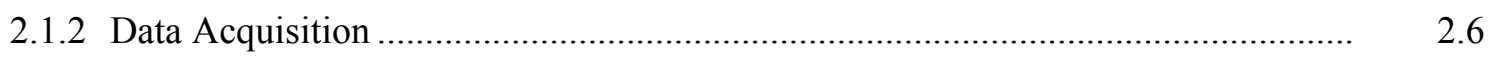

2.2 Strong Motion Accelerometer Stations …..................................................................... 2.7

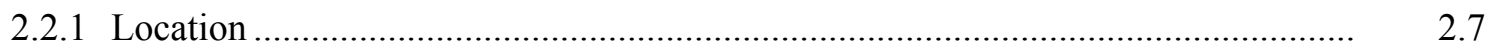

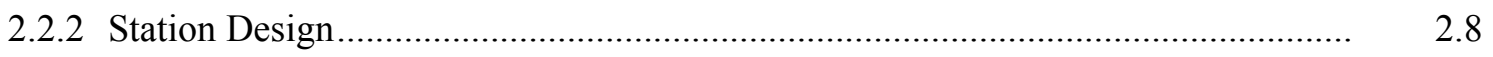

2.2.3 Strong Motion Accelerometer Operations Center …........................................... 2.8

2.2.4 Strong Motion Operational Characteristics ….................................................. 2.9

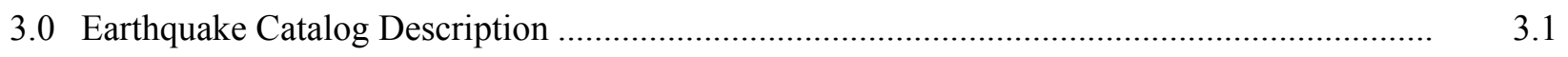

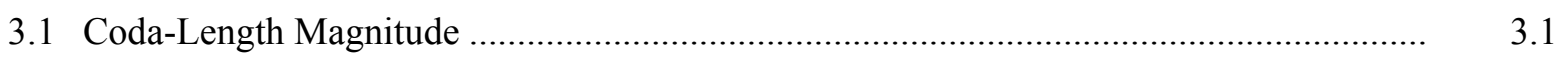

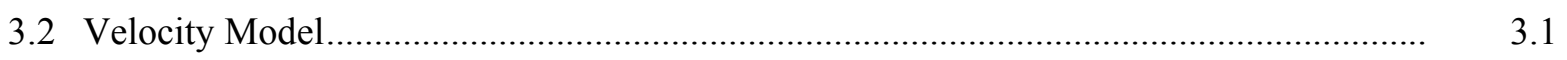

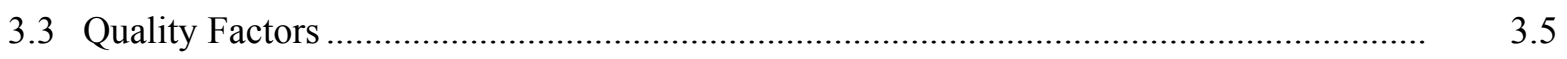

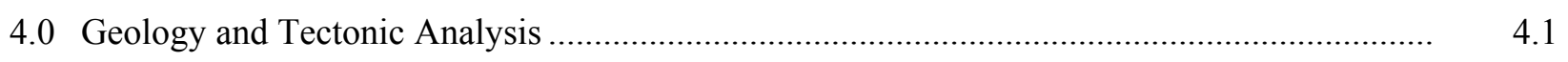

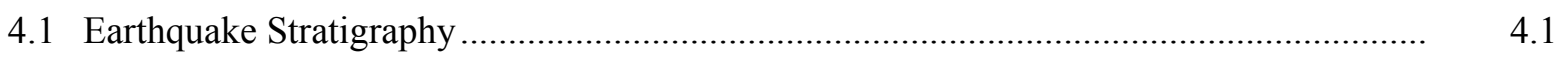

4.2 Geologic Structure Beneath the Monitored Area .........................................................

4.3 Tectonic Pattern............................................................................................................. 4.4

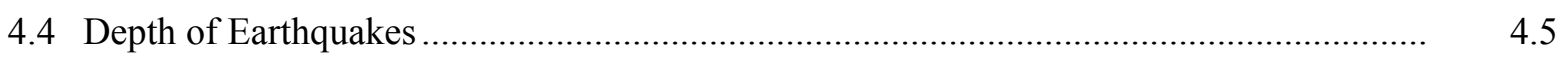

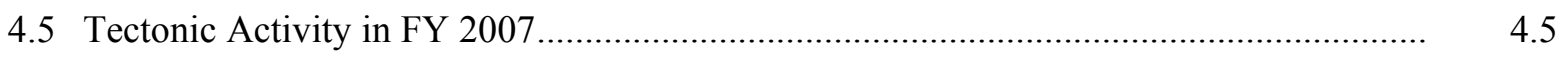

4.5.1 First-Quarter Earthquakes of FY 2007 ........................................................... 4.7

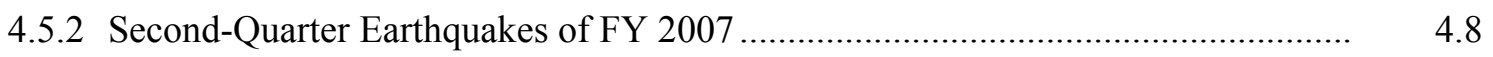

4.5.3 Third-Quarter Earthquakes of FY 2007 ............................................................ 4.8

4.5.4 Fourth-Quarter Earthquakes of FY 2007 .........................................................

5.0 Strong Motion Accelerometer Operations - FY 2007 Triggers.......................................... 5.1

6.0 Capabilities in the Event of a Significant Earthquake......................................................

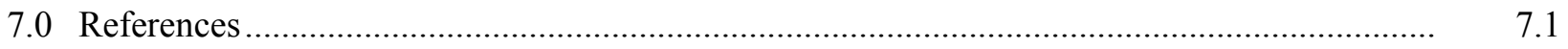




\section{Figures}

2.1 Seismometer and Strong Motion Accelerometer Stations in the Hanford

Seismic Network

2.2

2.2 Seismometer Stations in the Eastern Washington Regional Network

2.3 Repair of Locke Island Seismometer Station

2.5

2.4 Schematic Diagram of a Strong Motion Accelerometer Installation

2.9

4.1 Physical and Structural Geology of the Hanford Site, Washington...

4.2

4.2 Geologic Cross Sections Through the Columbia Basin...

4.3 FY 2007 Earthquakes Recorded Within the Hanford Monitoring Area

4.4 Fourth-Quarter FY 2007 Earthquakes Recorded in the Hanford Monitoring Area

5.1 April 16, 2007, Microearthquake Acceleration Time Histories at 300 Area SMA.

5.2

5.2 April 16, 2007, Microearthquake Acceleration Time Histories at 400 Area SMA.

\section{Tables}

2.1 Seismometer Stations in the Hanford Seismic Network

2.2 Seismometer Stations in the Eastern Washington Regional Network

2.3 Free-Field Strong Motion Accelerometer Sites

2.4 Instrument Parameters for the Kinemetrics ETNA System in the Hanford SMA Network

3.1 Local Seismic Data, October 1, 2006, Through September 30, 2007

3.2 Crustal Velocity Model for Eastern Washington

4.1 Thicknesses of Stratigraphic Units in the Monitoring Area.....

4.2 Number of Local Earthquakes Occurring in Stratigraphic Units

4.3 Earthquake Locations for FY 2007 


\subsection{Introduction}

This annual report documents the locations, magnitudes, and geologic interpretations of earthquakes recorded for the Hanford monitoring region of south-central Washington in fiscal year 2007 (October 2006 through September 2007). The report provides summaries of seismic events recorded during the first three quarters of fiscal year 2007 and contains a more comprehensive discussion of seismic events for the fourth quarter of the fiscal year. Comprehensive discussions of seismic activity occurring during the first three quarters of fiscal year 2007 may be found in previously published quarterly reports (Rohay et al. 2007a, 2007b, 2007c).

\subsection{Mission}

The principal mission of the Hanford Seismic Assessment Program (HSAP) is to maintain the seismometer and strong motion accelerometer (SMA) sites, report data from measured events, and provide assistance in the event of an earthquake. This mission supports the U.S. Department of Energy (DOE) and the other Hanford contractors in their compliance with DOE Order 420.1B, Chapter IV, Section 3.d "Seismic Detection" and DOE Order G 420.1-1, Section 4.7, "Emergency Preparedness and Emergency Communications." DOE Order 420.1B requires facilities or sites with hazardous materials to maintain instrumentation or other means to detect and record the occurrence and severity of the seismic event. The HSAP maintains the seismic network located on and around the Hanford Site. The data collected from the seismic network can be used to support facility or site operations to protect the public, workers, and the environment from the impact of seismic events.

In addition, the HSAP provides an uninterrupted collection of high-quality raw seismic data from the Hanford Seismic Network (HSN) located on and around the Hanford Site, and the Eastern Washington Regional Network (EWRN). The program provides interpretations of seismic events from the Hanford Site and vicinity, locates and identifies sources of seismic activity, monitors changes in the historical pattern of seismic activity, and builds a "local" earthquake database (processed data) that is permanently archived. The focus of this report is the precise location of earthquakes proximal to or on the Hanford Site, specifically between 46 degrees and 47 degrees north latitude and between 119 degrees and 120 degrees west longitude. Data from the EWRN and other seismic networks in the northwest provide the Seismic Assessment Project with necessary regional input for the seismic hazards analysis at the Hanford Site. These seismic data are used to support Hanford Site contractors for waste management activities, natural phenomena hazards assessments, and engineering design and construction.

\subsection{History of Monitoring Seismic Activity at Hanford}

Assessing seismic activity at the Hanford Site was initiated in 1969 by the U.S. Geological Survey (USGS) under a contract with the U.S. Atomic Energy Commission. In 1975, the University of Washington (UW) assumed responsibility for the network and subsequently expanded it. In 1979, the Basalt Waste Isolation Project (BWIP) became responsible for collecting seismic data for the Hanford Site as part of site characterization activities. Rockwell Hanford Operations, followed by Westinghouse Hanford Company (WHC), operated the local network and were the contract technical advisors for the EWRN operated and maintained by UW. Funding ended for BWIP in December 1988; the seismic program (including the UW contract) was transferred to the WHC Environmental Division. Maintenance 
responsibilities for the EWRN also were assigned to WHC, who made major upgrades to EWRN sites. Effective October 1, 1996, all seismic assessment activities were transferred to the Pacific Northwest National Laboratory (PNNL). ${ }^{1}$

The Hanford SMA network was constructed during 1997, becoming operational in May 1997. It was shut down in fiscal year 1998 due to lack of funding but became operational again in fiscal year 1999 and has operated continuously since that time.

\subsection{Documentation and Reports}

The HSAP issues quarterly reports of local activity, an annual catalog of earthquake activity in southeastern Washington, and special-interest bulletins on local seismic events. This includes information and special reports as requested by DOE and Hanford contractors. Earthquake information provided in these reports is subject to revision as new information becomes available. In addition, an archive of all seismic data from the HSAP is maintained by PNNL on computer servers.

\footnotetext{
${ }^{1}$ Pacific Northwest National Laboratory is operated by Battelle for the U.S. Department of Energy under Contract DE-AC05-76RL01830.
} 


\subsection{Network Operations}

\subsection{Seismometer Stations}

The seismic network consists of two types of earthquake sensors - seismometers and strong motion accelerometers (SMAs). Seismometers are designed primarily to detect microearthquakes near Hanford recording seismograms that are used to determine the magnitudes and locations of seismic events. SMA stations are designed to measure ground motion and are discussed in Section 2.2.

The HSN and the EWRN consist of 41 seismometer stations. Most stations reside in remote locations and require solar panels and batteries for power. The HSN includes 23 stations (Table 2.1 and Figure 2.1), and the EWRN consists of 36 stations (Table 2.2 and Figure 2.2). Eighteen stations are shared by both networks. Note that the Bickelton (BLT) station is shown on Figure 2.2.

Table 2.1. Seismometer Stations in the Hanford Seismic Network

\begin{tabular}{|c|c|c|c|c|}
\hline Station $^{(a)}$ & $\begin{array}{c}\text { Latitude } \\
\text { Deg. Min. N }\end{array}$ & $\begin{array}{c}\text { Longitude } \\
\text { Deg. Min. W }\end{array}$ & Elevation (m) & Station Name \\
\hline BEN & $46 \mathrm{~N} 31.13$ & 119W43.02 & 340 & Benson Ranch \\
\hline BLT & $45 \mathrm{~N} 54.91$ & 120W10.55 & 659 & Bicklelton \\
\hline BRV & $46 \mathrm{~N} 29.12$ & 119W59.47 & 920 & Black Rock Valley \\
\hline BVW & $46 \mathrm{~N} 48.66$ & 119W52.99 & 670 & Beverly \\
\hline $\mathrm{CRF}$ & $46 \mathrm{~N} 49.50$ & $119 \mathrm{~W} 23.22$ & 189 & Corfu \\
\hline ET3 & $46 \mathrm{~N} 34.64$ & $118 \mathrm{~W} 56.25$ & 286 & Eltopia Three \\
\hline $\mathrm{FHE}^{(\mathrm{b})}$ & 46N57.11 & 119W29.82 & 455 & Frenchman Hills East \\
\hline $\mathrm{GBB}^{(\mathrm{b})}$ & $46 \mathrm{~N} 36.49$ & 119W37.62 & 177 & Gable Butte \\
\hline GBL & $46 \mathrm{~N} 35.92$ & 119W27.58 & 330 & Gable Mountain \\
\hline $\mathrm{H} 2 \mathrm{O}$ & $46 \mathrm{~N} 23.75$ & 119W25.38 & 158 & Water \\
\hline LOC & $46 \mathrm{~N} 43.02$ & 119W25.85 & 210 & Locke Island \\
\hline MDW & $46 \mathrm{~N} 36.79$ & 119W45.66 & 330 & Midway \\
\hline MJ2 & $46 \mathrm{~N} 33.45$ & 119W21.54 & 146 & May Junction Two \\
\hline OT3 & $46 \mathrm{~N} 40.14$ & $119 \mathrm{~W} 13.98$ & 322 & Othello Three \\
\hline PRO & $46 \mathrm{~N} 12.73$ & 119W41.15 & 550 & Prosser \\
\hline RED & $46 \mathrm{~N} 17.92$ & $119 \mathrm{~W} 26.30$ & 366 & Red Mountain \\
\hline RSW & $46 \mathrm{~N} 23.67$ & 119W35.48 & 1,045 & Rattlesnake Mountain \\
\hline SNI & $46 \mathrm{~N} 27.85$ & 119W39.60 & 312 & Snively Ranch \\
\hline VT2 & $46 \mathrm{~N} 58.04$ & 119W58.95 & 1,270 & Vantage Two \\
\hline WA2 & $46 \mathrm{~N} 45.32$ & $119 \mathrm{~W} 33.94$ & 244 & Wahluke Slope \\
\hline WIW & $46 \mathrm{~N} 25.76$ & 119W17.26 & 128 & Wooded Island \\
\hline WRD & $46 \mathrm{~N} 58.20$ & 119W08.69 & 375 & Warden \\
\hline YPT & $46 \mathrm{~N} 02.93$ & 118W57.73 & 325 & Yellepit \\
\hline \multicolumn{5}{|c|}{$\begin{array}{l}\text { (a) The first column is the alphanumeric seismic station designator. The latitude and longitude, elevation above sea level in } \\
\text { meters, and the full station name follow this. The locations of the stations all are in Washington; locations were derived } \\
\text { from the Global Positioning System (GPS). }\end{array}$} \\
\hline
\end{tabular}




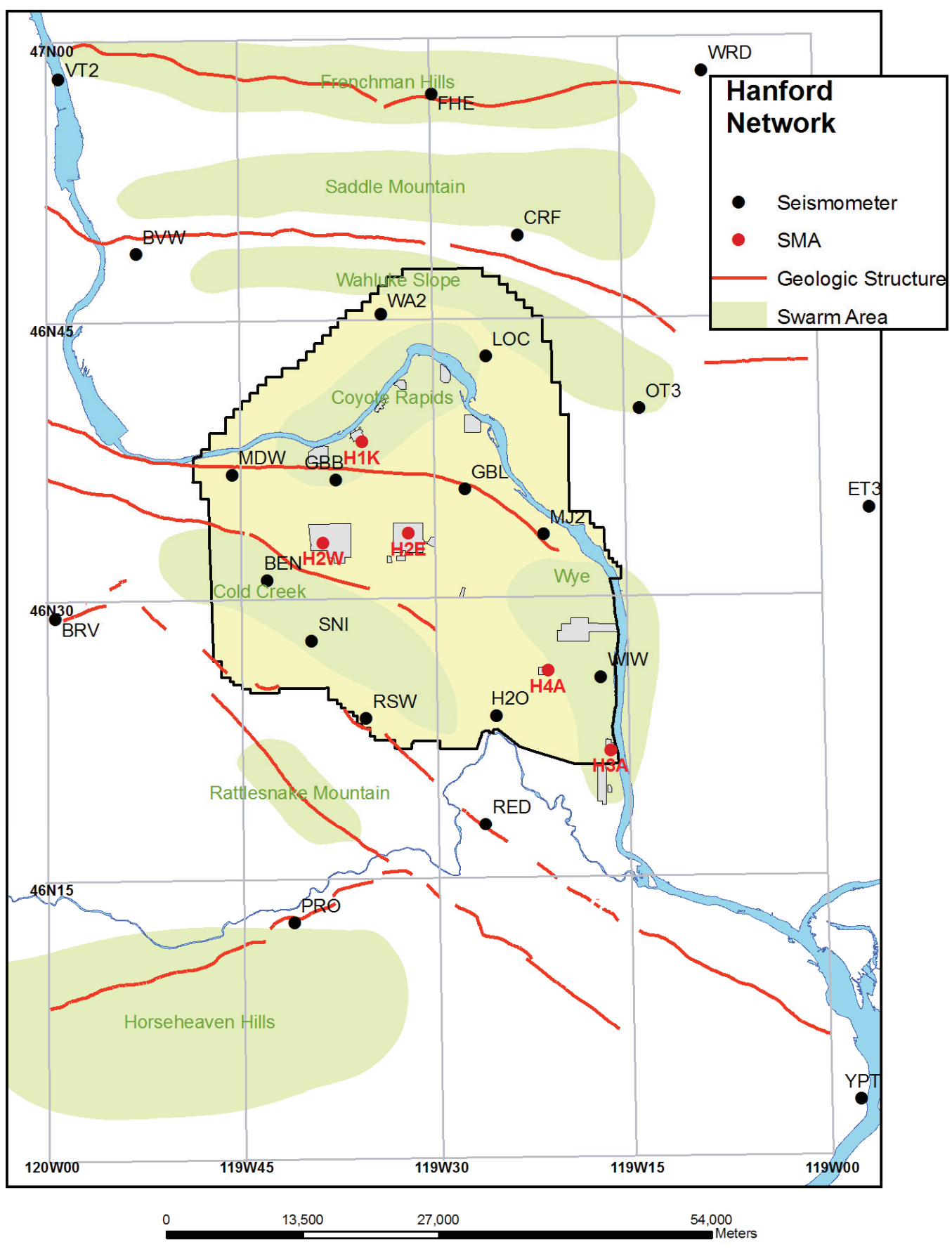

Figure 2.1. Seismometer and Strong Motion Accelerometer Stations in the Hanford Seismic Network 
Table 2.2. Seismometer Stations in the Eastern Washington Regional Network

\begin{tabular}{|c|c|c|c|c|}
\hline Station $^{(a)}$ & $\begin{array}{c}\text { Latitude } \\
\text { Deg. Min. N. }\end{array}$ & $\begin{array}{c}\text { Longitude } \\
\text { Deg. Min. W. }\end{array}$ & Elevation (m) & Station Name \\
\hline BLT & $45 \mathrm{~N} 54.91$ & $120 \mathrm{~W} 10.55$ & 659 & Bickleton \\
\hline BRV & $46 \mathrm{~N} 29.12$ & 119W59.47 & 920 & Black Rock Valley \\
\hline BVW & $46 \mathrm{~N} 48.66$ & 119W52.99 & 670 & Beverly \\
\hline CBS & $47 \mathrm{~N} 48.26$ & 120W02.50 & 1,067 & Chelan Butte South \\
\hline $\mathrm{CRF}$ & $46 \mathrm{~N} 49.50$ & $119 \mathrm{~W} 23.22$ & 189 & Corfu \\
\hline DPW & $47 \mathrm{~N} 52.25$ & $118 \mathrm{~W} 12.17$ & 892 & Davenport \\
\hline DY2 & $47 \mathrm{~N} 59.11$ & 119W46.28 & 890 & Dyer Hill Two \\
\hline ELL & $46 \mathrm{~N} 54.58$ & 120W33.98 & 789 & Ellensburg \\
\hline EPH & $47 \mathrm{~N} 21.38$ & 119W35.76 & 661 & Ephrata \\
\hline ET3 & $46 \mathrm{~N} 34.64$ & 118W56.25 & 286 & Eltopia Three \\
\hline ETW & $47 \mathrm{~N} 36.26$ & 120W19.94 & 1,477 & Entiat \\
\hline $\mathrm{FHE}^{(\mathrm{b})}$ & $46 \mathrm{~N} 57.11$ & 119W29.82 & 455 & Frenchman Hills East \\
\hline GBL & $46 \mathrm{~N} 35.92$ & 119W27.58 & 330 & Gable Mountain \\
\hline LNO & $45 \mathrm{~N} 52.31$ & 118W17.11 & 771 & Lincton Mountain Oregon \\
\hline LOC & $46 \mathrm{~N} 43.02$ & $119 \mathrm{~W} 25.85$ & 210 & Locke Island \\
\hline MDW & $46 \mathrm{~N} 36.79$ & 119W45.66 & 330 & Midway \\
\hline MJ2 & $46 \mathrm{~N} 33.45$ & $119 \mathrm{~W} 21.54$ & 146 & May Junction Two \\
\hline MOX & $46 \mathrm{~N} 34.64$ & 120W17.89 & 501 & Moxee City \\
\hline NAC & $46 \mathrm{~N} 43.99$ & 120W49.42 & 728 & Naches \\
\hline NEL & $48 \mathrm{~N} 04.21$ & $120 \mathrm{~W} 20.41$ & 1,500 & Nelson Butte \\
\hline OD2 & $47 \mathrm{~N} 23.26$ & 118W42.58 & 553 & Odessa Two \\
\hline OT3 & $46 \mathrm{~N} 40.14$ & 119W13.98 & 322 & Othello Three \\
\hline PAT2 & $45 \mathrm{~N} 53.03$ & $119 \mathrm{~W} 45.40$ & 259 & Paterson Two \\
\hline PRO & $46 \mathrm{~N} 12.73$ & $119 \mathrm{~W} 41.15$ & 550 & Prosser \\
\hline RSW & $46 \mathrm{~N} 23.67$ & $119 \mathrm{~W} 35.48$ & 1,045 & Rattlesnake Mountain \\
\hline SAW & $47 \mathrm{~N} 42.10$ & $119 \mathrm{~W} 24.03$ & 701 & St. Andrews \\
\hline TBM & $47 \mathrm{~N} 10.20$ & $120 \mathrm{~W} 35.88$ & 1,006 & Table Mountain \\
\hline TRW & $46 \mathrm{~N} 17.32$ & $120 \mathrm{~W} 32.31$ & 723 & Toppenish Ridge \\
\hline TWW & 47N08.29 & $120 \mathrm{~W} 52.10$ & 1,027 & Teanaway \\
\hline VT2 & $46 \mathrm{~N} 58.04$ & 119W58.95 & 1,270 & Vantage Two \\
\hline WA2 & $46 \mathrm{~N} 45.32$ & 119W33.94 & 244 & Wahluke Slope Two \\
\hline WAT & $47 \mathrm{~N} 41.92$ & $119 W 57.24$ & 821 & Waterville \\
\hline WIW & $46 \mathrm{~N} 25.76$ & $119 \mathrm{~W} 17.26$ & 128 & Wooded Island \\
\hline WRD & $46 \mathrm{~N} 58.20$ & 119W08.69 & 375 & Warden \\
\hline YA2 & $46 \mathrm{~N} 31.60$ & $120 \mathrm{~W} 31.80$ & 652 & Yakima Two \\
\hline YPT & $46 \mathrm{~N} 02.93$ & 118W57.73 & 325 & Yellepit \\
\hline \multicolumn{5}{|c|}{$\begin{array}{l}\text { (a) The first column is the alphanumeric seismic station designator. The latitude and longitude, elevation above sea level in } \\
\text { meters, and the full station name follow this. The locations of the stations all are in Washington unless otherwise } \\
\text { indicated; locations were determined from the Global Positioning System (GPS). } \\
\text { (b) Three-component station. }\end{array}$} \\
\hline
\end{tabular}




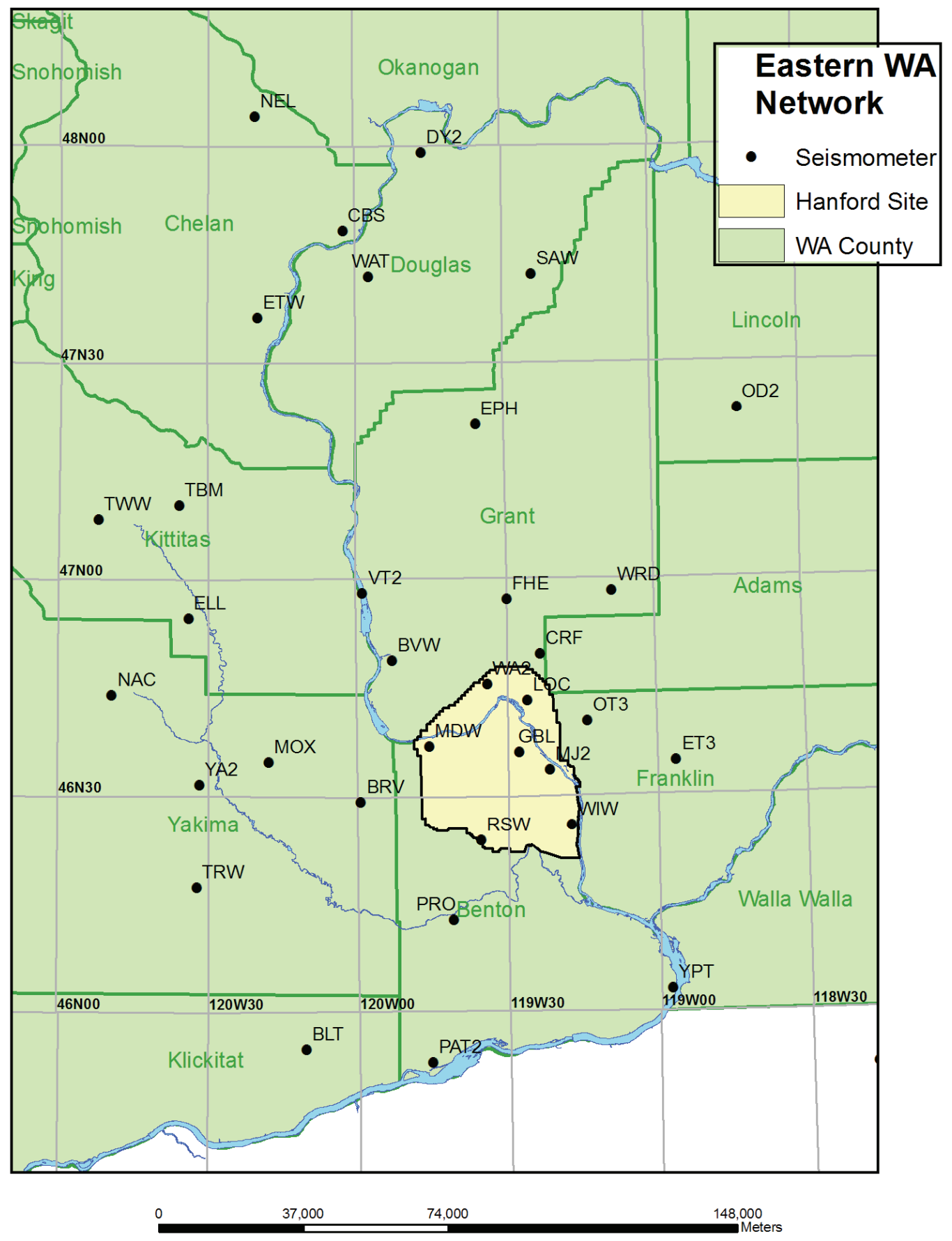

Figure 2.2. Seismometer Stations in the Eastern Washington Regional Network

The networks have 45 combined data channels because the Gable Butte and Frenchman Hills East stations are three-component sites, each consisting of vertical, north-south horizontal, and east-west horizontal components requiring 4 additional data channels. The other 41 stations are single vertical component seismometers. Fifteen radio telemetry relay sites are used by both networks to continuously transmit seismogram data to the Seismic Assessment Laboratory in the Sigma V building, Richland, Washington, for processing and archiving. 


\subsubsection{Station Maintenance}

During the fourth quarter of FY 2007, two fires burned large areas of the Hanford Site perimeter land managed by the U.S. Fish and Wildlife Service - the Fitzner/Eberhardt Arid Lands Ecology Reserve Unit in the southwestern portion of the Hanford Site and the Wahluke Unit north of the Columbia River. Both suffered extensive damage. Four sites of the HSN_Locke Island (LOC), Snively Ranch SNI), Benson Ranch (BEN), and Rattlesnake Mountain (RSW) - are located in the burn areas. Surface wiring and transmission coaxial cable had to be replaced at LOC and RSW (Figure 2.3). Due to the site design (buried vaults and cable, shielded cable above ground), damage to the seismic instruments and electronics was minor.

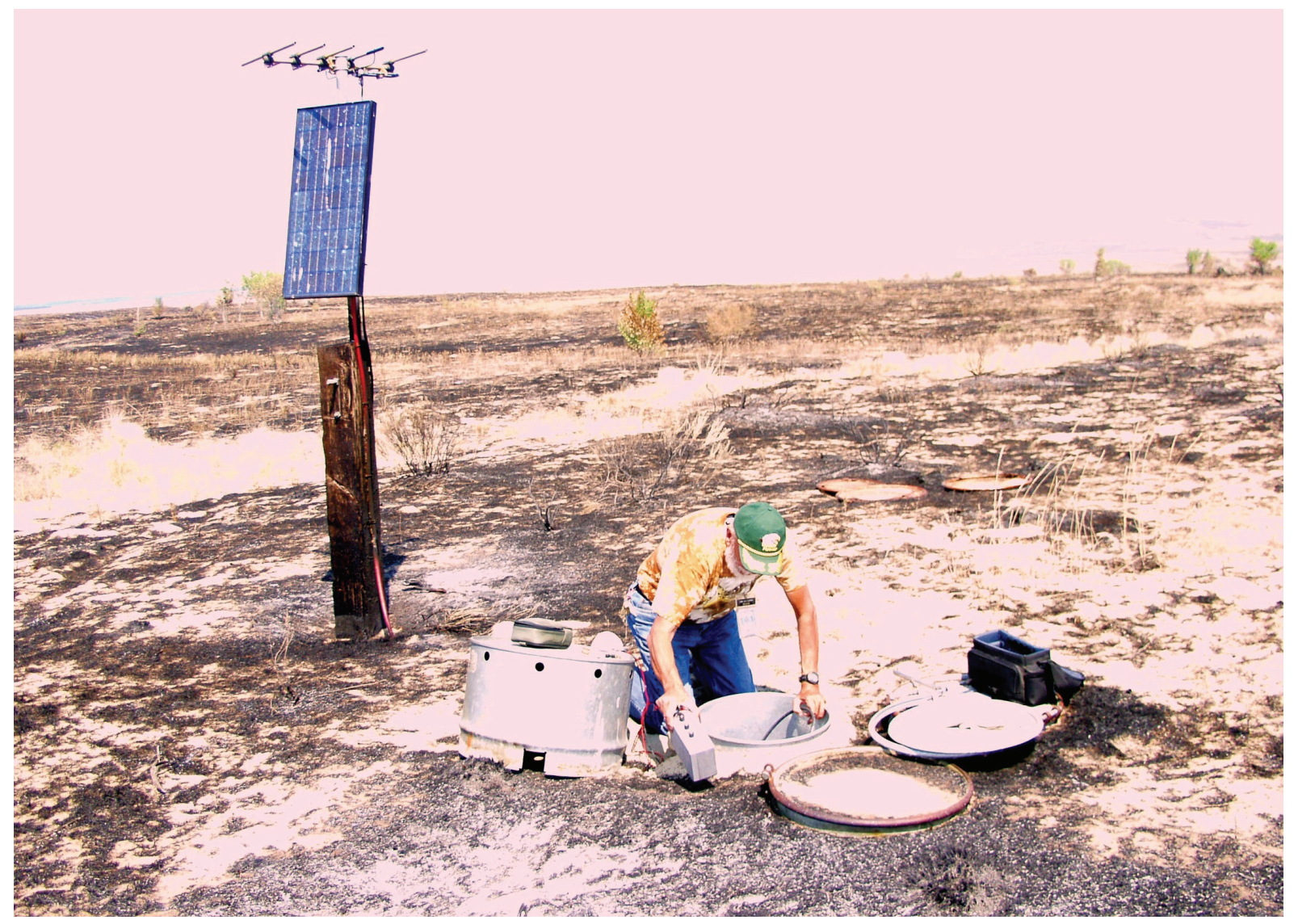

Figure 2.3. Repair of Locke Island Seismometer Station (LOC)

The northern sites of the EWRN were visited during a planned rendezvous with University of Washington (UW) technician Karl Hagel. Work was performed at the Chelan Butte South Relay (CBSR) station to reestablish telecommunications with the disconnected stations at Sugar Loaf (SLF) and Wenatchee Ridge (WRW). These two UW stations use the EWRN network as a pathway to the Bonneville Power Administration Waterville microwave station. The operational failure of SLF and WRW during winter inaccessibility resulted in transmission interference from the EWRN northern stations. The UW stations were disconnected until late summer when repairs were made at SLF and WRW. During the northern excursion, contact was made with the new owner of the property where the Waterville station is located. Continued access to and use of the Waterville site was granted by the new owner. 
During FY 2007, the HSAP began upgrading the Hanford seismometer network with the ultimate goal of replacing analog radio telemetry with digital, Internet-based telemetry. The upgrade will help eliminate the reliance on aging radio receiving and multiplexing equipment currently located in the Seismic Assessment Laboratory in the Sigma V building. The first upgrade is planned for the GBB station, to be equipped with triaxial broadband seismometers with built-in digitizing and telemetry equipment. A data recording unit and packet baler (Models Q330 and PB14F, Quanterra, Inc., Harvard, Massachusetts) and a solar controller (ProStar Model PS-15, Morningstar Corporation, Washington Crossing, Pennsylvania) were installed during the fourth quarter of FY 2007. Elevated fire alerts and the limitations to off-road travel on the Hanford Site during the late summer months delayed the upgrades to the Gable Butte station (GBB) for the triaxial broadband seismometer with built-in digitizing and telemetry equipment. The GBB station will be connected to the seismic network during the first quarter of FY 2008.

Efforts are under way to acquire three broadband seismometer stations currently owned by the Incorporated Research Institutions for Seismology (IRIS) program. IRIS is a national geophysics research program operated by the National Science Foundation (NSF). These stations are located at Black Rock, Eltopia, and Paterson, Washington. As the IRIS research is completed in the western states, the NSF intends to transfer the stations to regional seismic monitoring programs such as HSAP. Acquisition costs for these stations are at large discount compared to standard equipment purchase and installation costs. These triaxial seismometer stations are equipped with digital recorders and telemetry gear and can detect a much broader range of seismic events than current HSN stations. The HSAP plans to acquire the IRIS stations during FY 2008.

\subsubsection{Data Acquisition}

The signals from the seismometer stations are monitored for changes in signal amplitude that are expected from earthquakes. The seismic network is subdivided into spatial groupings of stations that are monitored for nearly simultaneous amplitude changes, resulting in triggering a permanent recording of the events. The groupings and associated weighting schemes are designed to allow very small seismic events to be recorded and to minimize false triggers. Events are classified as local (south-central Washington near the Hanford Site), regional (western United States and Canada), and teleseisms (from farther distances around the world). Local and regional events are usually earthquakes, but quarry and mining explosions also are recorded. Quarry and mining explosions usually can be identified from wave characteristics and the time of occurrence and may be confirmed with local government agencies and industries. Frequently, military exercises at the U.S. Army Yakima Training Center produce a series of

acoustic shocks that trigger the recording system. Sonic booms and thunder also produce acoustic signals that may trigger the recording system.

The HSAP uses Earthworm, a PC-based system developed by the USGS and used by the Pacific Northwest Seismic Network at the UW, to record triggered events. One Earthworm system has been in continuous operation since January 6, 1999. A second system was installed in mid-March 1999. Both systems have been running in parallel since that time, with periodic hardware and software upgrades performed. Seismogram data from triggered events are collected on a SUN workstation (Sun Microsystems, Santa Clara, California) for assessment by HSAP staff. This information is evaluated to 
determine if the event is "false" (for example, due to a sonic boom) or is an earthquake or ground-surface or underground blast. Earthquake events are evaluated to determine epicenter locations, focal depths, and magnitudes (Section 3).

Although the two Earthworm systems are practically identical, slight differences in the trigger algorithms, combined with the granularity of the signal-measurement time windows, sometimes result in triggered events from one Earthworm system but not the other. These different or exclusive events are generally "false" triggers resulting from acoustical sources and not earthquakes or quarry blasts. Sometimes these exclusive events correspond to barely detectable, distant regional, or teleseismic earthquakes.

\subsection{Strong Motion Accelerometer Stations}

\subsubsection{Location}

The Hanford SMA network consists of five free-field SMA stations (see Figure 2.1; Table 2.3). SMAs are located in the 200 East and 200 West Areas, in the $100 \mathrm{~K}$ Area adjacent to the K Basins, in the 400 Area near the Fast Flux Test Facility, and at the south end of the 300 Area. With the termination of the Fast Flux Test Facility program, plans have been made to move the 400 Area station to a new location.

Table 2.3. Free-Field Strong Motion Accelerometer Sites

\begin{tabular}{|c|c|c|c|}
\hline Site & Site ID & Location & $\begin{array}{l}\text { Latitude } \\
\text { Longitude } \\
\text { Elevation }\end{array}$ \\
\hline $100 \mathrm{~K}$ Area & $\mathrm{H} 1 \mathrm{~K}$ & South of K Basins outside 100 Area fence lines & $\begin{array}{l}46^{\circ} 38.51^{\prime} \\
119^{\circ} 35.53 \\
152 \mathrm{~m}\end{array}$ \\
\hline 200 East Area & $\mathrm{H} 2 \mathrm{E}$ & $\begin{array}{l}\text { East of B Plant; northwest of Waste Treatment and } \\
\text { Immobilization Plant; north of } 7 \text { th Street and east of } \\
\text { Baltimore Avenue }\end{array}$ & $\begin{array}{l}46^{\circ} 33.58^{\prime} \\
119^{\circ} 32.00^{\circ} \\
210 \mathrm{~m}\end{array}$ \\
\hline 200 West Area & $\mathrm{H} 2 \mathrm{~W}$ & $\begin{array}{l}\text { West of Plutonium Finishing Plant (PFP) and } 200 \text { West Area } \\
\text { tree barrier }\end{array}$ & $\begin{array}{l}46^{\circ} 33.11^{\prime} \\
119^{\circ} 38.64^{\prime} \\
201 \mathrm{~m}\end{array}$ \\
\hline 300 Area & $\mathrm{H} 3 \mathrm{~A}$ & $\begin{array}{l}\text { South end of } 300 \text { Area inside fence lines (NE 1/4, SW 1/4, } \\
\text { Sec. 11, T10N, R28E) }\end{array}$ & $\begin{array}{l}46^{\circ} 21.83^{\prime} \\
119^{\circ} 16.55^{\circ} \\
119 \mathrm{~m}\end{array}$ \\
\hline 400 Area & $\mathrm{H} 4 \mathrm{~A}$ & $\begin{array}{l}500 \mathrm{ft} \text { from fence line on east side of facility and north of } \\
\text { parking area) }\end{array}$ & $\begin{array}{l}46^{\circ} 26.13^{\prime} \\
119^{\circ} 21.30^{\prime} \\
171 \mathrm{~m}\end{array}$ \\
\hline
\end{tabular}

The SMA stations were chosen based on two criteria (Moore and Reidel 1996): instruments should be located in areas 1) having the highest densities of workers and 2) containing hazardous facilities. Hanford workers are situated at the 200 East and 200 West Areas, $100 \mathrm{~K}$ Area, the Fast Flux Test Facility (400 Area), and the 300 Area. The 200 Areas are where high-level radioactive waste from past processing of fuel rods is stored in single-shell and double-shell tanks. In addition, the Canister Storage Facility that holds encapsulated spent fuel rods is in the 200 East Area, and the new Waste Treatment and Immobilization Plant is being constructed in the 200 East Area. The $100 \mathrm{~K}$ Area contains the K Basins, 
where spent fuel rods from the $\mathrm{N}$ Reactor are stored prior to encapsulation. The Cold Vacuum Drying Facility, located in the $100 \mathrm{~K}$ Area, is used to encapsulate spent fuel rods from the K Basins prior to shipment to the Canister Storage Building in the 200 East Area.

\subsubsection{Station Design}

All free-field SMA stations consist of a four-panel solar array and two 30-gal galvanized drums. Each panel has a maximum 42-W output. The two 30-gal drums are set in the ground such that the base of each drum is about $1 \mathrm{~m}$ below the ground surface. One drum houses only the SMA; the other drum, which is connected via a sealed conduit to the SMA drum, contains the batteries. Communication is through a General Packet Radio Service (GPRS) system, which provides a continuous radio data-link with an Internet service provider. This GPRS system along with the solar power regulator is housed in a small enclosure mounted at the rear of the solar array. The enclosure serves as a junction box for all cabling between equipment inside and outside the drums through conduit. The antenna for the GPRS is mounted on top of the enclosure. The enclosure permits quick access to check battery conditions and a connection directly to the RS-232 port of the SMA without removing the drum lids.

The SMA instruments are three-component units consisting of one vertical, one north-south horizontal, and one east-west horizontal data channel. The instruments in use are the ETNA system (Kinemetrics, Inc., Pasadena, California). Instrument specifications are summarized in Table 2.4. Each ETNA unit contains a digital recorder, data storage unit, and Global Positioning System (GPS) receiver (Figure 2.4). These components are housed in a watertight box.

The GPRS system provides the Internet address connection to access the system. Stations can be monitored from any computer with appropriate access, and data can be downloaded to a dedicated computer in the Seismic Assessment Laboratory. The data also can be downloaded directly at each site via a built-in cable connection at the enclosure in case of communication failure.

The GPS receiver is used principally to access the National Bureau of Standards timing system. ${ }^{2}$ The GPS receiver is activated internally approximately every $4 \mathrm{hr}$ and checks the "location of the instrument" and the time. Any differences between the internal clock and the GPS time are recorded by the SMA. Any corrections to the internal timing are made automatically. Typically, the greatest correction recorded is approximately 4 milliseconds (ms).

\subsubsection{Strong Motion Accelerometer Operations Center}

The combined operations, data recording, data interpretation, and maintenance facility is located in the Sigma V Building and is operated by the HSAP.

\footnotetext{
2 The GPS receiver antenna is mounted on the enclosure at the rear of the solar array.
} 
Table 2.4. Instrument Parameters for the Kinemetrics ETNA System in the Hanford SMA Network

\begin{tabular}{|c|c|}
\hline Parameter & Value or Range \\
\hline \multicolumn{2}{|r|}{ Sensor } \\
\hline Type & Triaxial EpiSensor Accelerometer \\
\hline Full-scale & $\pm 2 \mathrm{~g}^{(\mathrm{a})}$ \\
\hline Frequency range & $0-80 \mathrm{~Hz}$ \\
\hline Damping & Approximately $70 \%$ critical $^{(\mathrm{a})}$ \\
\hline \multicolumn{2}{|r|}{ Data Acquisition } \\
\hline Number of channels & 3 \\
\hline Sample rate & 200 samples/sec \\
\hline Resolution & 18 bits \\
\hline Digital output & Real-time, RS-232 output stream \\
\hline \multicolumn{2}{|r|}{ Seismic Trigger } \\
\hline Filter & $0.1-12.5 \mathrm{~Hz}$ \\
\hline Trigger level & $0.02 \% \mathrm{~g}^{(\mathrm{b})}$ \\
\hline Alarm (call-out) threshold & Not activated \\
\hline Pre-event memory & $10 \mathrm{~s}$ \\
\hline Post-event time & $40 \mathrm{~s}$ \\
\hline $\begin{array}{l}\text { (a) Setting is dependent or } \\
\text { (b) See Section 2.2.4 for d }\end{array}$ & $\begin{array}{l}\text { trument calibration. } \\
\text { ssion of trigger thresholds. }\end{array}$ \\
\hline
\end{tabular}

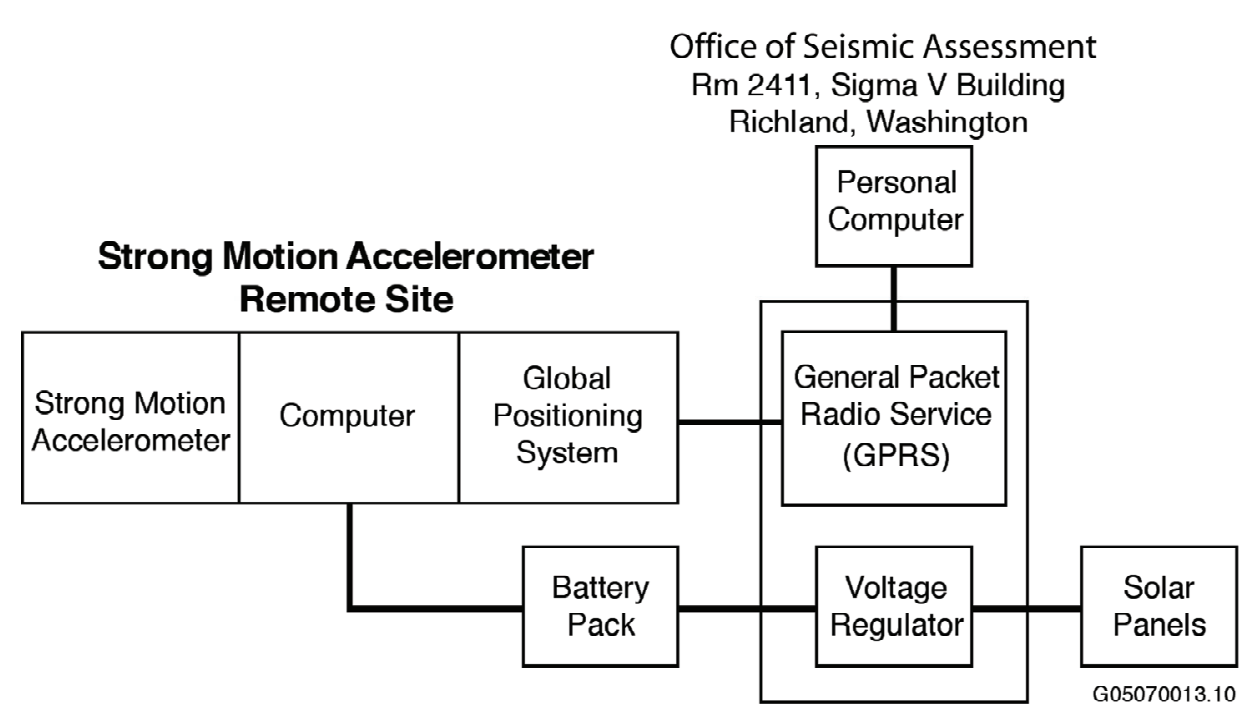

Figure 2.4. Schematic Diagram of a Strong Motion Accelerometer Installation

\subsubsection{Strong Motion Operational Characteristics}

Signals from the three accelerometer channels use an 18-bit digitizer with data temporarily stored in a memory buffer. The digital sampling rate is 200 samples/s. The three channels are monitored for signals that exceed a programmable trigger threshold. When one accelerometer channel is triggered, the other 
channels automatically record. The nominal threshold used from 1998 to 2006 was $0.1 \% \mathrm{~g}(0.05 \%$ of the full-scale range of $2.0 \mathrm{~g}$; $\mathrm{g}$ is the acceleration of gravity, $9.8 \mathrm{~m} / \mathrm{s}^{2}$ or $32 \mathrm{ft} / \mathrm{s}^{2}$ ). Threshold trigger levels are set to trigger infrequently on noise sources (e.g., vehicles, sonic booms) near each site. In 2006, larger data storage capacities were installed that allowed the trigger thresholds to be reduced to $0.02 \% \mathrm{~g}$ (see Section 5). This permits the recording of ground motion data for smaller, non-damaging earthquakes that can be useful in estimating impacts of larger earthquakes. It also helps confirm correct operation of the instruments by analyzing the smaller-amplitude triggers. During continuous operation, the recorders save information for $10 \mathrm{~s}$ before overwriting the data buffers. Upon exceeding the trigger threshold, the data are recorded for $40 \mathrm{~s}$ and saved so that the information may be retrieved by HSAP staff. 


\subsection{Earthquake Catalog Description}

An interactive program called XPED, developed at the University of Washington, is used to determine earthquake locations and magnitudes. This program reads seismogram data recorded by the Earthworm system and lets the user measure arrival times and durations from earthquakes. Arrival and duration times are used as input to the hypocenter routine within XPED to estimate locations and magnitudes of the seismic events. XPED results for local earthquakes $\left(46^{\circ}-47^{\circ} \mathrm{N}\right.$ latitude, $119^{\circ}-120^{\circ} \mathrm{W}$ longitude) are reported in Table 3.1. Other seismic events located in southeastern Washington, the Pacific Northwest, or outside the region also are evaluated, with results stored on the computer system; these results are not reported in this document. These other results sometimes are used as a check to confirm that the HSN is functioning properly (e.g., quality checks on data recording).

\subsection{Coda-Length Magnitude}

Coda-length magnitude $\left(\mathrm{M}_{\mathrm{c}}\right)$, an estimate of local magnitude $\left(\mathrm{M}_{\mathrm{L}}\right)$ (Richter 1958), is calculated using a relationship developed for Washington State by Crosson (1972):

$$
\mathrm{M}_{\mathrm{c}}=2.82 \log (\mathrm{D})-2.46
$$

where $\mathrm{D}$ is the duration of the observed event. Many of the earthquakes have magnitude determinations that are very small $\left(\mathrm{M}_{\mathrm{c}}<0\right)$ and highly uncertain. In Section 4 we define earthquakes as "minor" with magnitudes $\left(\mathrm{M}_{\mathrm{c}}\right)$ smaller than 1.0. Coda-length magnitudes for events classified as explosions are not reported because they are biased by a prominent surface wave that extends the apparent duration in a way inconsistent with coda-length measurement.

\subsection{Velocity Model}

XPED uses the crustal velocity model for eastern Washington given in Table 3.2. The model does not include a surficial layer for the Hanford or Ringold formations because most seismometer stations are sited on basalt. The crustal velocity model extends $38 \mathrm{~km}$ deep (to the mantle) and consists of six layers, each with uniform seismic velocity. The crustal velocity model was developed using available geologic information and calibrated from seismic data recorded from accurately located earthquake and blast events in eastern Washington. Time corrections (delays) are incorporated into the velocity model to account for significant deviations in station elevations or stations situated on sedimentary layers. Station delays also are determined empirically from accurately located earthquakes and blast events in the region. 


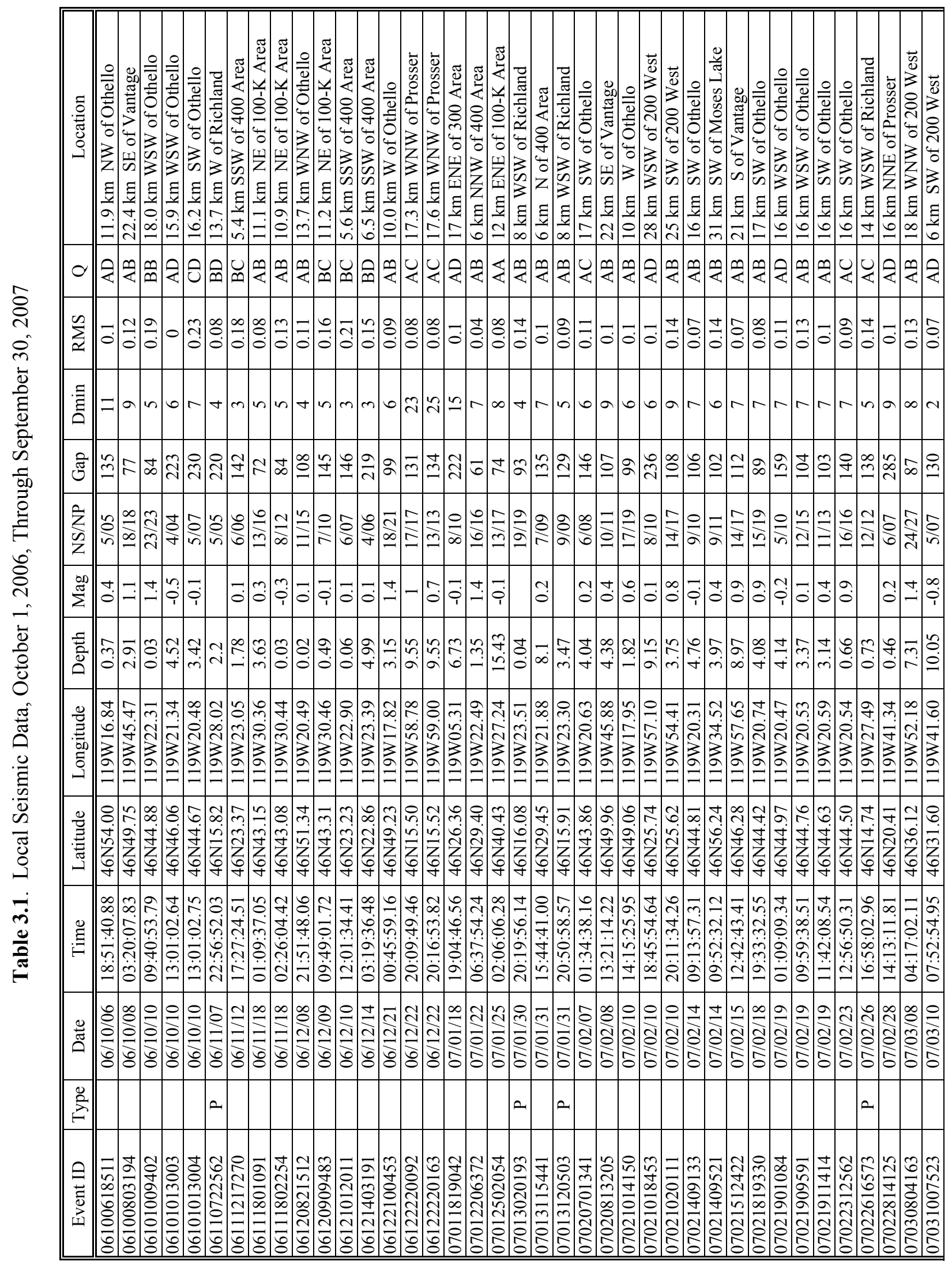




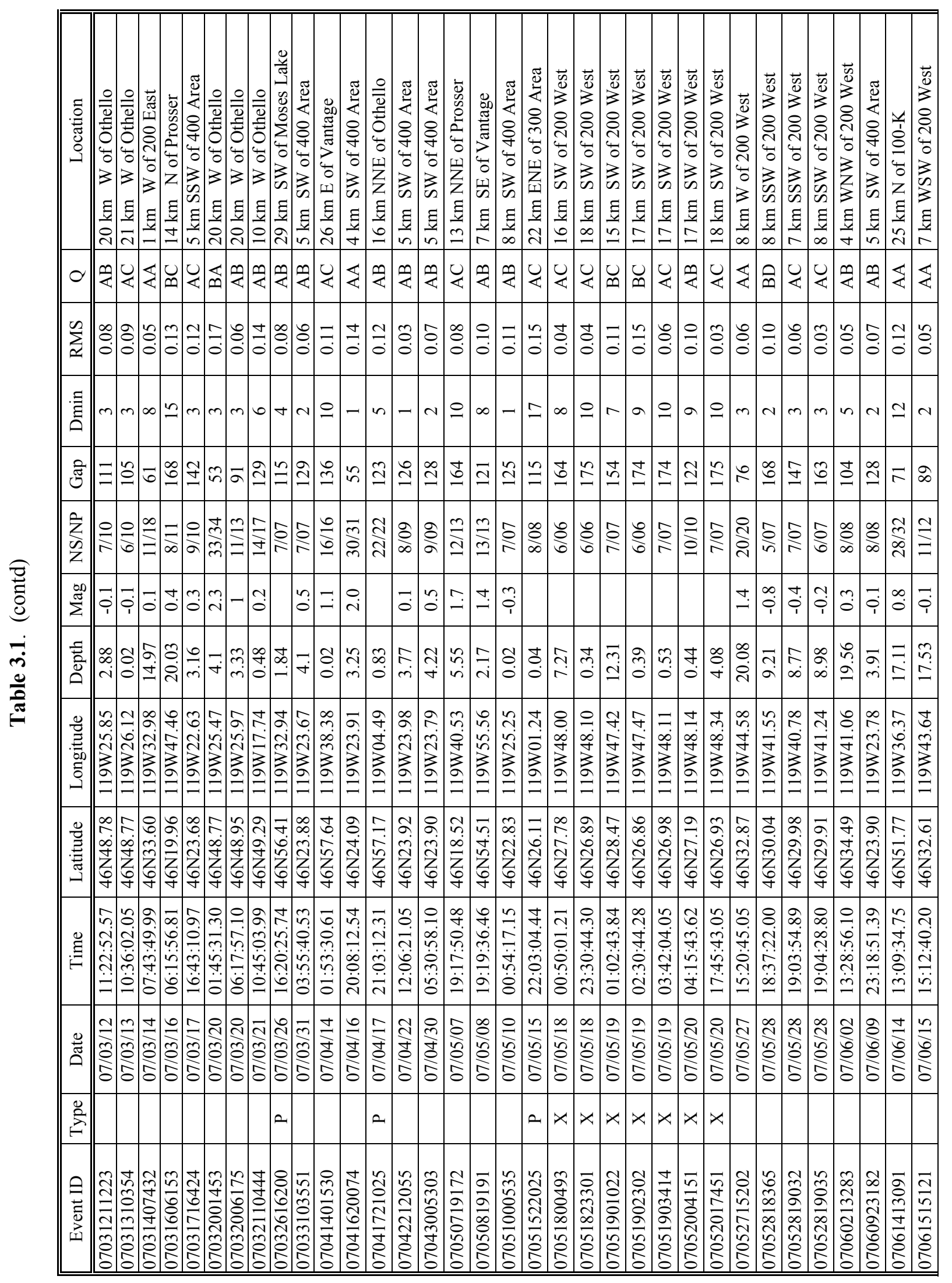




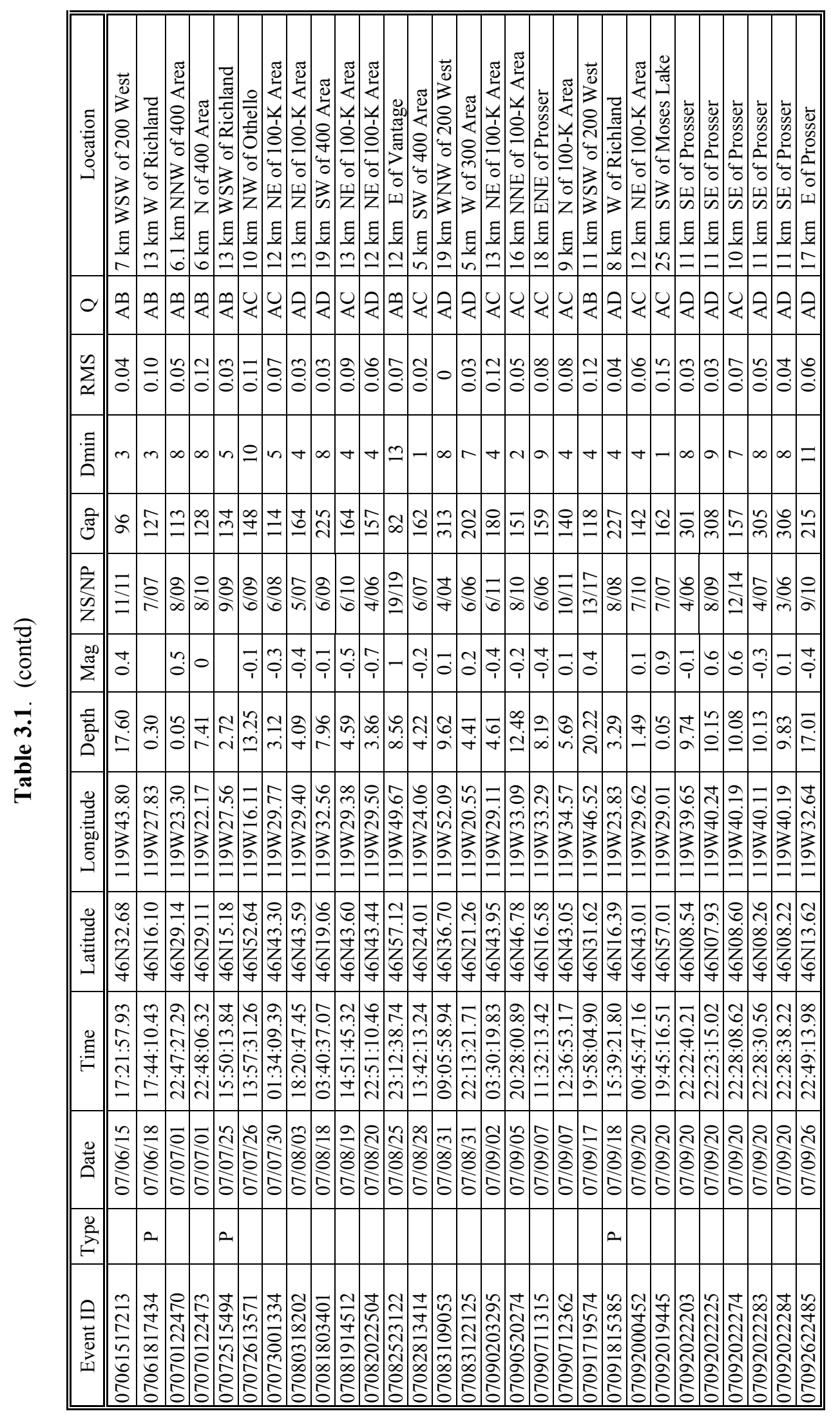


Explanation of Table 3.1

Event ID: The Earthworm recording system creates the identification number. XPED uses the year, month, day, and time to create a unique number for each event.

Type: $\quad \mathrm{P}$ is Probable Blast; $\mathrm{X}$ is Confirmed Blast; F is Felt Earthquake; blank is local earthquake.

Date: The year and day of the year in Universal Time Coordinated (UTC). UTC is used throughout this report unless otherwise indicated.

Time: $\quad$ The origin time of the earthquake given in Coordinated Universal Time (UTC). To covert UTC to Pacific Standard Time, subtract eight hours; to Pacific Daylight Time, subtract seven hours.

Latitude: North latitude, in degrees and minutes, of the earthquake epicenter.

Longitude: West longitude, in degrees and minutes, of the earthquake epicenter.

Depth: The depth of the earthquake in kilometers $(\mathrm{km})$.

Mag: $\quad$ The magnitude is expressed as coda-length magnitude $\mathrm{M}_{\mathfrak{c}}$, an estimate of local magnitude $\mathrm{M}_{\mathrm{L}}$ (Richter 1958). If magnitude is blank, a determination was not made.

NS/NP: $\quad$ Number of stations/number of phases used in the solutions.

Gap: $\quad$ Azimuthal gap; the largest angle (relative to the epicenter) containing no stations.

DMIN: The distance from the earthquake epicenter to the closest station.

RMS: The root-mean-square residual (observed arrival times minus the predicted arrival times) at all stations used to locate the earthquake. It is useful as a measure of quality of the solution only when five or more well-distributed stations are used in the solution. Good solutions are normally characterized by RMS values of less than about $0.3 \mathrm{~s}$.

Q: $\quad$ Quality factors; indicate the general reliability of the solution/location (A is best quality, D is worst). See Section 3.3 of this report, "Quality Factors."

\subsection{Quality Factors (Q)}

XPED assigns a two-letter Quality factor (Table 3.1) that indicates the general reliability of the solution (A is best quality, $\mathbf{D}$ is worst). Similar quality factors are used by the USGS for events located with the computer program HYPO71. The first letter of the quality code is a measure of the hypocenter quality based primarily on arrival time residuals. For example: Quality A requires a root-mean-square residual (RMS) less than $0.15 \mathrm{~s}$, while a RMS of $0.5 \mathrm{~s}$ or more is $\mathbf{D}$ quality (other estimates of the location uncertainty also affect this quality parameter). The second letter of the quality code is related to the spatial distribution of stations that contribute to the event location, including the number of stations (NS), the number of p-wave and s-wave phases (NP), the largest gap in event-station azimuth distribution (GAP), and the closest distance from the epicenter to a station (DMIN). Quality A requires a solution with $\mathbf{N P}>8, \mathbf{G A P}<90^{\circ}$, and $\mathbf{D M I N}<5 \mathrm{~km}$ (or the hypocenter depth if it is greater than $5 \mathrm{~km}$ ). If $\mathbf{N P} \leq 5$, GAP $>180^{\circ}$, or DMIN $>50 \mathrm{~km}$, the solution is assigned Quality $\mathbf{D}$. 
Table 3.2. Crustal Velocity Model for Eastern Washington (from Rohay et al. 1985)

\begin{tabular}{||c|l|c||}
\hline $\begin{array}{c}\text { Depth to Top of } \\
\text { Velocity Layer }(\mathrm{km})\end{array}$ & \multicolumn{1}{|c|}{ Layer } & $\begin{array}{c}\text { Velocity } \\
(\mathrm{km} / \mathrm{s})\end{array}$ \\
\hline \hline 0.0 & Saddle Mountains and Wanapum Basalts and intercalated Ellensburg Formation & 3.7 \\
\hline 0.4 & Grande Ronde Basalt and pre-basalt sediments & 5.2 \\
\hline 8.5 & Crystalline basement, Layer 1 & 6.1 \\
\hline 13.0 & Crystalline basement, Layer 2 & 6.4 \\
\hline 23.0 & Sub-basement & 7.1 \\
\hline 38.0 & Mantle & 7.9 \\
\hline
\end{tabular}




\subsection{Geology and Tectonic Analysis}

The Hanford Site lies within the Columbia Basin, an intermontane basin between the Cascade Range and the Rocky Mountains filled with Cenozoic volcanic rocks and sediments. This basin forms the northern part of the Columbia Plateau physiographic province (Fenneman 1931) and the Columbia River flood-basalt province (Reidel and Hooper 1989). In the central and western parts of the Columbia Basin, the Columbia River Basalt Group (CRBG) overlies Tertiary continental sedimentary rocks and is overlain by late Tertiary and Quaternary fluvial and glaciofluvial deposits (Campbell 1989; Reidel et al. 1989, 1994; DOE 1988). In the eastern part, a thin $(<100-\mathrm{m})$ sedimentary unit separates the basalt and underling crystalline basement, and a thin $(<10-\mathrm{m})$ veneer of eolian sediments overlies the basalt (Reidel et al. 1989, 1994).

The Columbia Basin has two structural subdivisions or subprovinces - the Yakima Fold Belt and the Palouse Slope. The Yakima Fold Belt includes the western and central parts of the Columbia Basin and is a series of anticlinal ridges and synclinal valleys with major thrust faults typically along the northern flanks (Figure 4.1) (Reidel and Fecht 1994a, 1994b). The Palouse Slope is the eastern part of the basin and is less deformed than the Yakima Fold Belt, with only a few faults and low-amplitude long-wavelength folds on an otherwise gently westward dipping paleoslope. Figure 4.2 shows north-south (B-B') and east-west $\left(\mathrm{A}-\mathrm{A}^{\prime}\right)$ cross sections through the Columbia Basin based on surface mapping (Reidel and Fecht 1994a, 1994b), deep boreholes (Reidel et al. 1994), geophysical data (Rohay et al. 1985; DOE 1988), and magnetotelluric data obtained as part of BWIP (DOE 1988).

\subsection{Earthquake Stratigraphy}

Seismic studies at the Hanford Site have shown that the earthquake activity is related to crustal stratigraphy (large groupings of rock types) (Rohay et al. 1985; DOE 1988). The main geologic units important to earthquakes at the Hanford Site and the surrounding area are

- the Miocene CBRG

- pre-basalt sediments of Paleocene, Eocene, Oligocene, and Early Miocene age

- the crystalline basement composed of Precambrian and Paleozoic craton/continental margin

- Mesozoic accreted terranes.

\subsection{Geologic Structure Beneath the Monitored Area}

Between the late 1950s and the mid 1980s, deep boreholes were drilled for hydrocarbon exploration in the Columbia Basin. These boreholes provided accurate measurements of the physical properties of the CRBG and the pre-basalt sediments (Reidel et al. 1989, 1994), but the thickness of the pre-basalt sediments and nature of the crystalline basement are still poorly understood. The difference between the thicknesses listed in Table 4.1 and the thicknesses of the crustal layers in the velocity model in Table 3.2 reflect data specific to UW's crustal velocity model for eastern Washington. Table 4.1, derived from Reidel et al. (1994), was developed for the geologic interpretation in this report. The thicknesses of these units are variable across the monitored area. Table 4.1 summarizes the approximate thickness at the borders of the monitored area. 


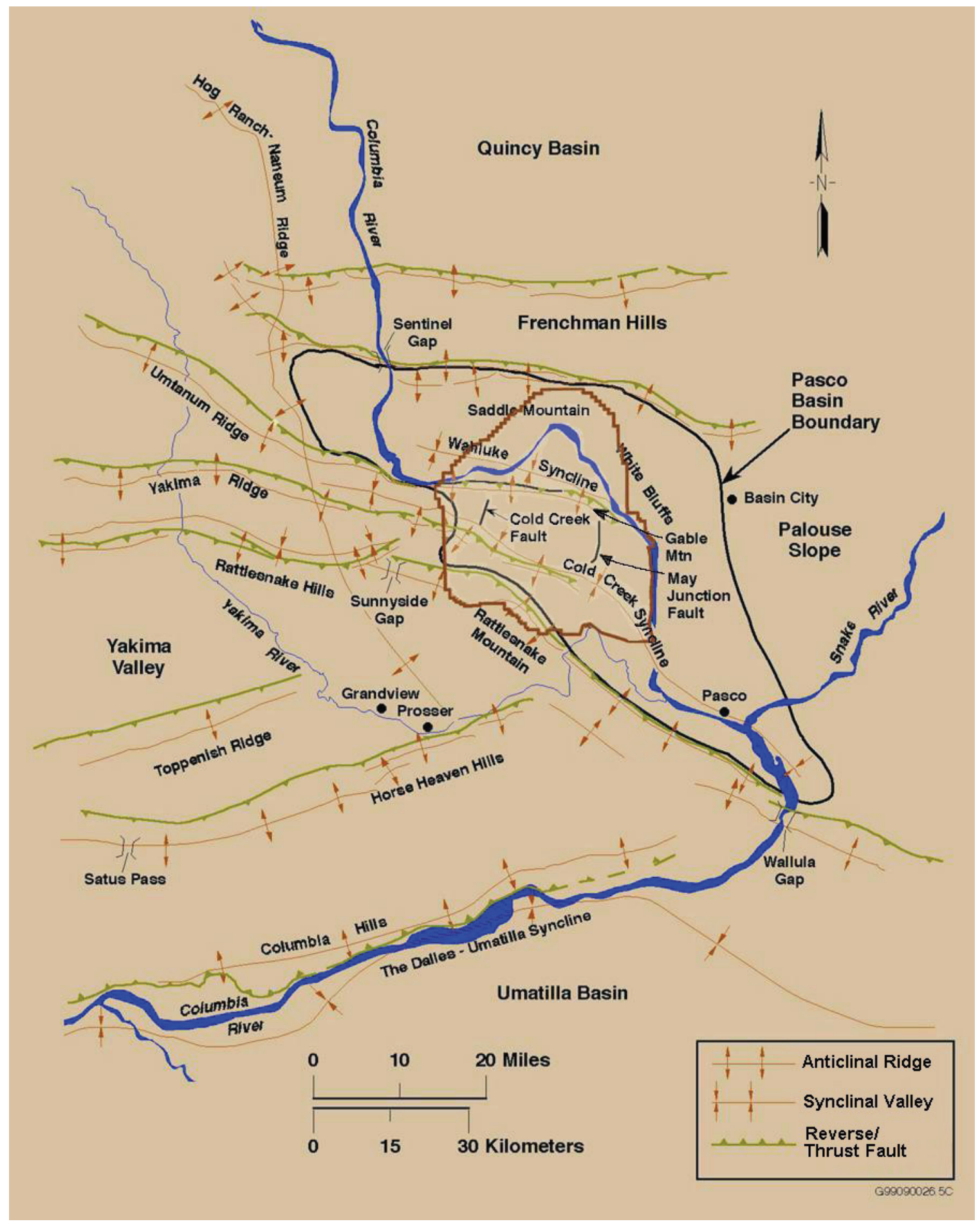

Figure 4.1. Physical and Structural Geology of the Hanford Site, Washington 

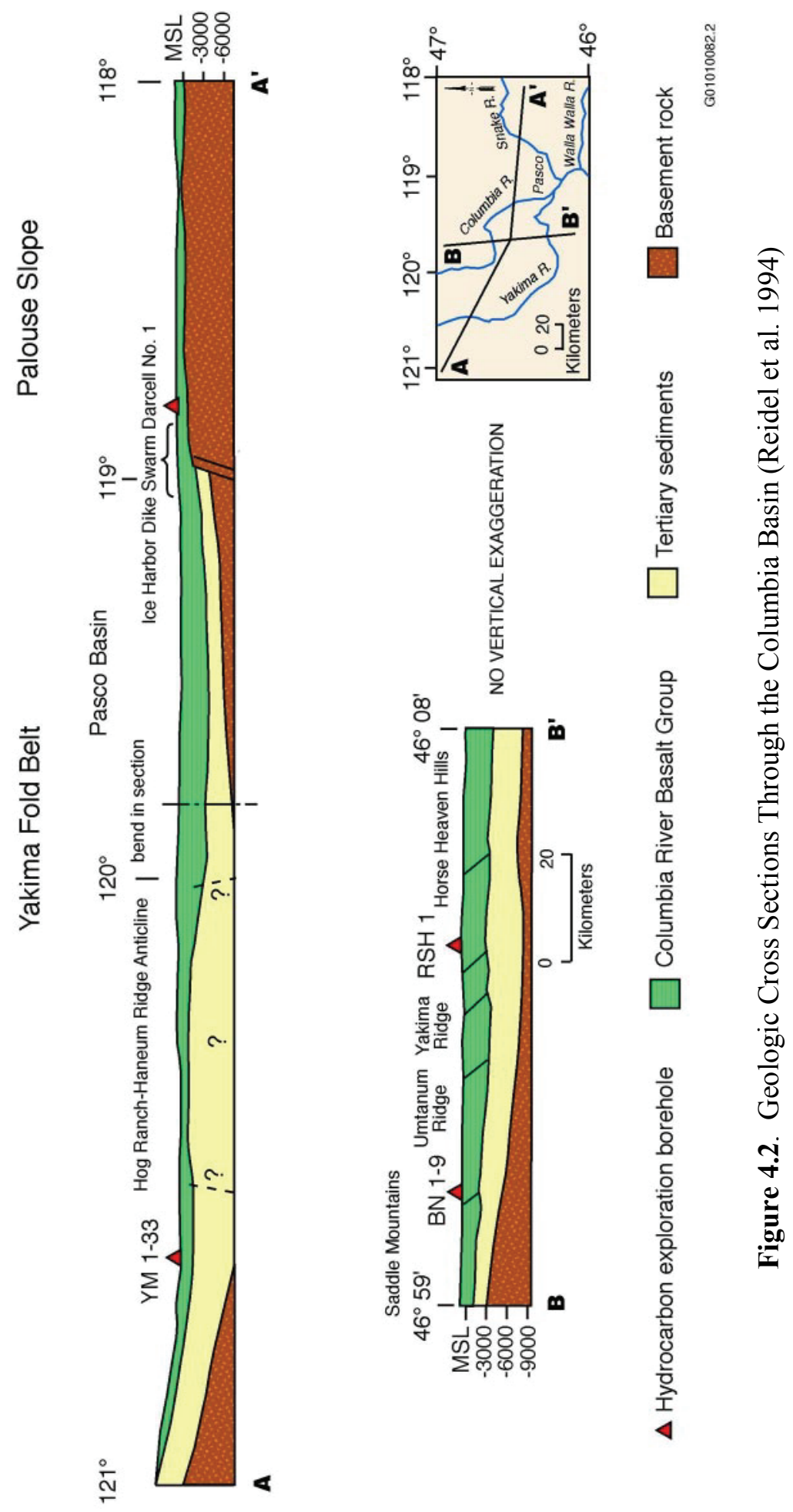
Table 4.1. Thicknesses of Stratigraphic Units in the Monitoring Area (from Reidel et al. 1994)

\begin{tabular}{||l|c|c|c|c||}
\hline \multicolumn{1}{|c|}{ Stratigraphy } & North & South & East & West \\
\hline \hline Columbia River Basalt Group (includes suprabasalt sediments) & $3.0 \mathrm{~km}$ & $4.5 \mathrm{~km}$ & $2.2 \mathrm{~km}$ & $4.2 \mathrm{~km}$ \\
\hline Pre-basalt sediments & $3.0 \mathrm{~km}$ & $>4.5 \mathrm{~km}$ & 0 & $>6.0 \mathrm{~km}$ \\
\hline
\end{tabular}

The thickness of the basalt and the pre-basalt sediments varies as a result of different tectonic environments. The western edge of the North American craton (late Precambrian/Paleozoic continental margin and Precambrian craton) is located in the eastern portion of the monitored area (Reidel et al. 1994). The stratigraphy on the craton consists of CRBG overlying crystalline basement; the crystalline basement is continental crustal rock that underlies much of the western North America. The stratigraphy west of the craton consists of 4 to $5 \mathrm{~km}$ of CRBG overlying up to $6 \mathrm{~km}$ of pre-basalt sediments. This in turn overlies accreted terranes of Mesozoic age. The area west of the craton was subsiding during the Eocene and Oligocene, accumulating great thickness of pre-CRBG sediments. Continued subsidence in this area during the Miocene resulted in thicker CRBG compared to that on the craton. Subsidence continues today but at a greatly reduced rate (Reidel et al. 1994).

\subsection{Tectonic Pattern}

Studies have concluded that earthquakes can occur in the following six different tectonic environments (earthquake sources) at the Hanford Site (Geomatrix 1996):

- major geologic structures - Reverse/thrust faults in the CRBG associated with major anticlinal ridges such as Rattlesnake Mountain, Yakima Ridge, and Umtanum Ridge could produce some of the largest earthquakes.

- secondary faults - These faults are typically smaller (1 to $20 \mathrm{~km}$ ) than the main reverse/thrust faults that occur along the major anticlinal ridges (up to $100 \mathrm{~km}$ ). Secondary faults can be segment boundaries (tear faults) and small faults of any orientation that formed along with the main structure.

- swarm areas - Small geographic areas not known to contain any geologic structures produce clusters of events (swarms), usually located in synclinal valleys. These clusters consist of a series of small shocks with no outstanding principal event. Swarms occur over a period of days or months, and the events may number into the hundreds and then quit, only to start again at a later date. This differs from the sequence of foreshocks, mainshock, and trailing-off aftershocks that have the same epicenter or are associated with the same fault system. In the past, swarms were thought to occur only in the CRBG. Most swarm areas are in the basalt, but swarm events also appear to occur in all geologic layers. However, typically a swarm event at a specific time is usually restricted to one layer. Seven earthquake swarm areas are recognized in the Hanford Seismic Network area, but this list will be updated as new swarm areas develop. The Saddle Mountains, Wooded Island, Wahluke, Coyote Rapids, and Horse Heaven Hills swarm areas are typically active at one time or another during the year (Figure 4.3). The other earthquake swarm areas are active less frequently.

- the entire Columbia Basin - The entire basin, including the Hanford Site, could produce a "floating" earthquake. A floating earthquake is one that, for seismic design purposes, can happen anywhere in a tectonic province and is not associated with any known geologic structure. Seismic interpretation classifies it as a random event for purposes of seismic design and vibratory ground motion studies. 
- basement source structures - Studies (Geomatrix 1996) suggest that major earthquakes can originate in tectonic structures in the crystalline basement. Because little is known about geologic structures in the crystalline basement beneath the Hanford Site, earthquakes cannot be directly tied to a mapped fault. Earthquakes occurring in the crystalline basement without known sources are treated as random events.

- the Cascadia subduction zone - This source has been postulated to be capable of producing a magnitude 9 earthquake. Because this source is along the western boundary of Washington State and outside the HSN, the Cascadia subduction zone is not an earthquake source that is monitored at the Hanford Site, so subduction zone earthquakes are not reported here. Because any earthquake along the Cascadia subduction zone can have a significant impact on the Hanford Site or can be felt like the February 2001 Nisqually earthquake, UW monitors and reports on this earthquake source for the DOE. Ground motion from any moderate or larger Cascadia subduction zone earthquake is detected by Hanford SMAs and reported (see Section 5).

\subsection{Depth of Earthquakes}

Since records have been kept, most of the earthquakes at the Hanford Site have originated in the CBRG layer. The crystalline basement has had the next greatest amount of earthquakes, followed by the pre-basalt sediments. The stratigraphic units for local earthquakes recorded during FY 2007 are listed in Table 4.2.

Table 4.2. Number of Local Earthquakes Occurring in Stratigraphic Units

\begin{tabular}{||l|c|c|c|c|c||}
\hline \multicolumn{1}{|c|}{ Unit } & First Quarter & Second Quarter & Third Quarter & Fourth Quarter & FY 2007 \\
\hline \hline Columbia River Basalt Group & 12 & 14 & 7 & 9 & $42(50 \%)$ \\
\hline Pre-basalt sediments & 1 & 8 & 1 & 3 & $13(15 \%)$ \\
\hline Crystalline basement & 2 & 7 & 8 & 13 & $30(35 \%)$ \\
\hline Total & 15 & 29 & 16 & 25 & $85(100 \%)$ \\
\hline
\end{tabular}

\subsection{Tectonic Activity in FY 2007}

During FY 2007, 85 events were recorded within the Hanford Seismic Monitoring Network (Table 3.1; Figure 4.3). Of those, $42(50 \%)$ were in the CBRG, $13(15 \%)$ in the pre-basalt sediments, and $30(35 \%)$ in the crystalline basement. One event was located near a geologic structure (Saddle Mountain anticline); 52 (62\%) were located in earthquake swarms; and 32 (37\%) were interpreted as random events. Earthquakes typically are classified as random if they are located in the pre-basalt or crystalline basement. Very little is known about geologic structures in these deeper layers, so precise interpretations are not possible. An earthquake can be classified as a random event also if it occurs in the basalt but is not located near any known geologic structure. 


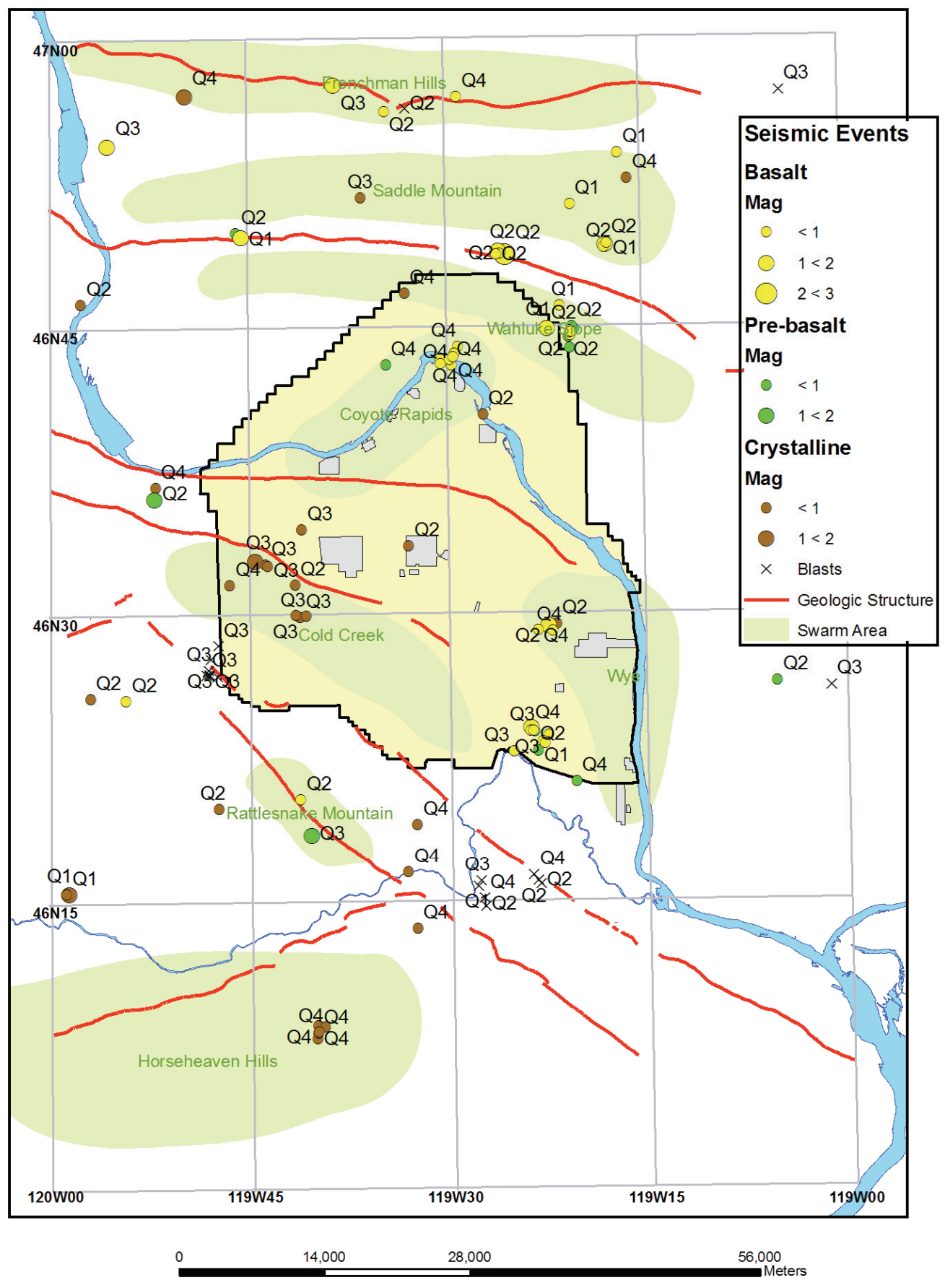

Figure 4.3. FY 2007 Earthquakes Recorded Within the Hanford Monitoring Area (October 2006 through September 2007) 
Table 4.3. Earthquake Locations for FY 2007

\begin{tabular}{|c|c|c|c|c|c|c|}
\hline & Seismic Sources & $\begin{array}{l}\text { First Quarter } \\
10 / 01-12 / 31\end{array}$ & $\begin{array}{c}\text { Second Quarter } \\
1 / 01-3 / 31\end{array}$ & $\begin{array}{c}\text { Third Quarter } \\
4 / 01-6 / 30\end{array}$ & $\begin{array}{c}\text { Fourth Quarter } \\
7 / 01-9 / 30\end{array}$ & FY 2007 \\
\hline \multicolumn{2}{|c|}{ Geologic Structure } & 1 & - & - & - & $1(1 \%)$ \\
\hline \multirow{9}{*}{$\begin{array}{l}\text { Swarm } \\
\text { Areas }\end{array}$} & Frenchman Hills & - & 1 & 1 & 2 & 4 \\
\hline & $\begin{array}{l}\text { Saddle Mountains/ } \\
\text { Royal Slope }\end{array}$ & 3 & 2 & 1 & 1 & 7 \\
\hline & Wahluke Slope & 3 & 7 & - & 1 & 11 \\
\hline & Coyote Rapids & 3 & 1 & - & 7 & 11 \\
\hline & Wye & - & 2 & - & 2 & 4 \\
\hline & Cold Creek & - & 1 & 6 & 1 & 8 \\
\hline & Rattlesnake Mountain. & - & 1 & 1 & - & 2 \\
\hline & Horse Heaven Hills & - & - & - & 5 & 5 \\
\hline & Total for swarm areas & 9 & 15 & 9 & 19 & $52(62 \%)$ \\
\hline \multicolumn{2}{|c|}{ Random Events } & 5 & 14 & 7 & 6 & $32(37 \%)$ \\
\hline \multicolumn{2}{|c|}{ Total for all earthquakes } & 15 & 29 & 16 & 25 & 85 \\
\hline
\end{tabular}

In Figure 4.3, the earthquake swarm areas were redefined, with all FY 2007 seismic events plotted on the map. This resulted in a more consistent interpretation of swarm events and minor adjustments to Table 4.3 for swarm events listed in the seismic reports for the second and third quarters (Rohay et al. 2007b, 2007c).

\subsubsection{First-Quarter Earthquakes of FY 2007 (October-December 2006)}

During the first quarter of FY 2007, sixteen events were recorded within the Hanford Seismic Monitoring Network (Table 3.1; Figure 4.3). Of the sixteen events, fifteen were determined to be earthquakes and one event was deemed to be a quarry blast (Figure 4.3). Nine events were located in swarm areas, one event was classified as located near a geologic structure, and five events were classified as random (Figure 4.3). Four of the fifteen recorded events with magnitudes greater than $1.0 \mathrm{M}_{\mathrm{c}}$ are discussed below.

\subsubsection{Major Anticlinal Ridges}

On October 8, 2006, an event located on the northern limb of the Saddle Mountains east of Sentinel Gap was recorded. The magnitude was $1.1 \mathrm{M}_{\mathrm{c}}$ with a depth of $2.91 \mathrm{~km}$ within the CBRG.

\subsubsection{Earthquake Swarm Areas}

On December 21, 2006, a magnitude $1.4 \mathrm{M}_{\mathrm{c}}$ earthquake was recorded near the eastern edge of the Saddle Mountain swarm area at approximately $3.2 \mathrm{~km}$ deep within the CBRG.

On October 10, 2006, a magnitude $1.4 \mathrm{M}_{\mathrm{c}}$ earthquake was recorded at a depth of less than $1 \mathrm{~km}$ within the CBRG. 


\subsubsection{Random or Floating Events}

On December 22, 2006, a magnitude $1.0 \mathrm{M}_{\mathrm{c}}$ earthquake was recorded at approximately $9.5 \mathrm{~km}$ deep within the crystalline basement. This event was located near the southwest Hanford Monitoring Area boundary.

\subsubsection{Second-Quarter Earthquakes of FY 2007 (January-March 2007)}

During the second quarter of FY 2007, thirty-three events were recorded within the Hanford Seismic Monitoring Network (Table 3.1; Figure 4.3). Of those, twenty-nine were determined to be earthquakes and four events deemed to be quarry blasts (Figure 4.3). Fifteen events occurred in swarm areas, and fourteen events were classified as random (Figure 4.3). Four of the twenty-nine recorded events had magnitudes greater than $1.0 \mathrm{M}_{\mathrm{c}}$ and are discussed below.

\subsubsection{Major Anticlinal Ridges}

No earthquakes were associated with the major geologic structures in the area surrounding the Hanford Site for the second quarter of FY 2007.

\subsubsection{Earthquake Swarm Areas}

\section{Wye Area Swarm}

On January 22, 2007, a magnitude $1.4 \mathrm{M}_{\mathrm{c}}$ event was recorded that was located at a depth of approximately $1.4 \mathrm{~km}$ within the CBRG.

\subsubsection{Random or Floating Events}

On March 20, 2007, a magnitude $2.3 \mathrm{M}_{\mathrm{c}}$ event was recorded that was located near the Saddle Mountains north of the "horn" area of the Columbia River. The depth was approximately $4.1 \mathrm{~km}$. Later that same day (March 20,2007), a magnitude $1.0 \mathrm{M}_{\mathrm{c}}$ event at nearly the same location was recorded, with depth approximately $3.3 \mathrm{~km}$. This places both events within the CBRG.

On March 8, 2007 a magnitude $1.4 \mathrm{M}_{\mathrm{c}}$ event was recorded that was located west of the Hanford boundary near the Columbia River at depth approximately $7.3 \mathrm{~km}$ within the pre-basalt sediments.

\subsubsection{Third-Quarter Earthquakes of FY 2007 (April-June 2007)}

During the third quarter of FY 2007, twenty-six events were recorded within the Hanford Seismic Monitoring Network (Table 3.1; Figure 4.3). Of the twenty-six events, sixteen were determined to be earthquakes and ten events deemed to be blasts (Figure 4.3). Nine events occurred in swarm areas, and the remaining seven were classified as random (Figure 4.3). Five of the sixteen recorded events had magnitudes greater than $1.0 \mathrm{M}_{\mathrm{c}}$ and are discussed below.

\subsubsection{Major Anticlinal Ridges}

No earthquakes were associated with the major geologic structures in the area surrounding the Hanford Site for the third quarter of FY 2007. 


\subsubsection{Earthquake Swarm Areas}

\section{Frenchman Hills Swarm Area}

On April 14, 2007, a magnitude $1.1 \mathrm{M}_{\mathrm{c}}$ earthquake was recorded in the Frenchman Hills swarm area. The depth of this event was approximately $0.02 \mathrm{~km}$, or near the ground surface, and within the CBRG.

\section{Cold Creek Swarm Area}

On May 27, 2007, a magnitude $1.4 \mathrm{M}_{\mathrm{c}}$ earthquake was recorded in the Cold Creek swarm area. The depth of this event was approximately $20.1 \mathrm{~km}$ within the crystalline basement.

\section{Rattlesnake Mountain Swarm Area}

On May 7, 2007, a magnitude of $1.7 \mathrm{M}_{\mathrm{c}}$ earthquake was recorded in the Rattlesnake Mountain swarm area. The depth of this event was approximately $5.6 \mathrm{~km}$ within the pre-basalt sediments.

\subsubsection{Random or Floating Events}

On April 16, 2007, a magnitude $2.0 \mathrm{M}_{\mathrm{c}}$ earthquake was located approximately $4 \mathrm{~km}$ southwest of the 400 Area at depth approximately $3.3 \mathrm{~km}$ within the CBRG. Another earthquake occurred on May 8 , 2007 , located about $7 \mathrm{~km}$ southeast of Vantage, Washington, with magnitude of $1.4 \mathrm{M}_{\mathrm{c}}$ and depth approximately $2.2 \mathrm{~km}$ within the CBRG.

\subsubsection{Fourth-Quarter Earthquakes of FY 2007 (July-September 2007)}

During the fourth quarter FY 2007, twenty-seven events were recorded within the Hanford Seismic Monitoring Network (Table 3.1; Figure 4.4). Of the twenty-seven events, twenty-five were determined to be earthquakes and two events deemed to be blasts (Figure 4.4). The fourth quarter summary (Table 4.2) shows that nine events $(36 \%)$ occurred in the CBRG; three events $(12 \%)$ occurred in the pre-basalt sediments; and thirteen events (52\%) occurred in the crystalline basement. Nineteen events occurred in swarm areas, and six events were classified as random (Figure 4.4). In the following discussion, minor earthquakes refer to seismic events for which the magnitude is less than $1.0 \mathrm{M}_{\mathrm{c.}}$.

\subsubsection{Major Anticlinal Ridges}

No earthquakes were associated with the major geologic structures in the area surrounding the Hanford Site for the fourth quarter of FY 2007.

\subsubsection{Earthquake Swarm Areas}

Nineteen earthquakes were characterized as swarm events in the fourth quarter of FY 2007.

\section{Frenchman Hills Swarm Area}

On August 25, 2007, a magnitude $1.0 \mathrm{M}_{\mathrm{c}}$ earthquake was recorded with depth approximately $8.6 \mathrm{~km}$ within the crystalline basement. On September 20, 2007, a minor earthquake was recorded at depth less than $1 \mathrm{~km}$ within the CBRG. 


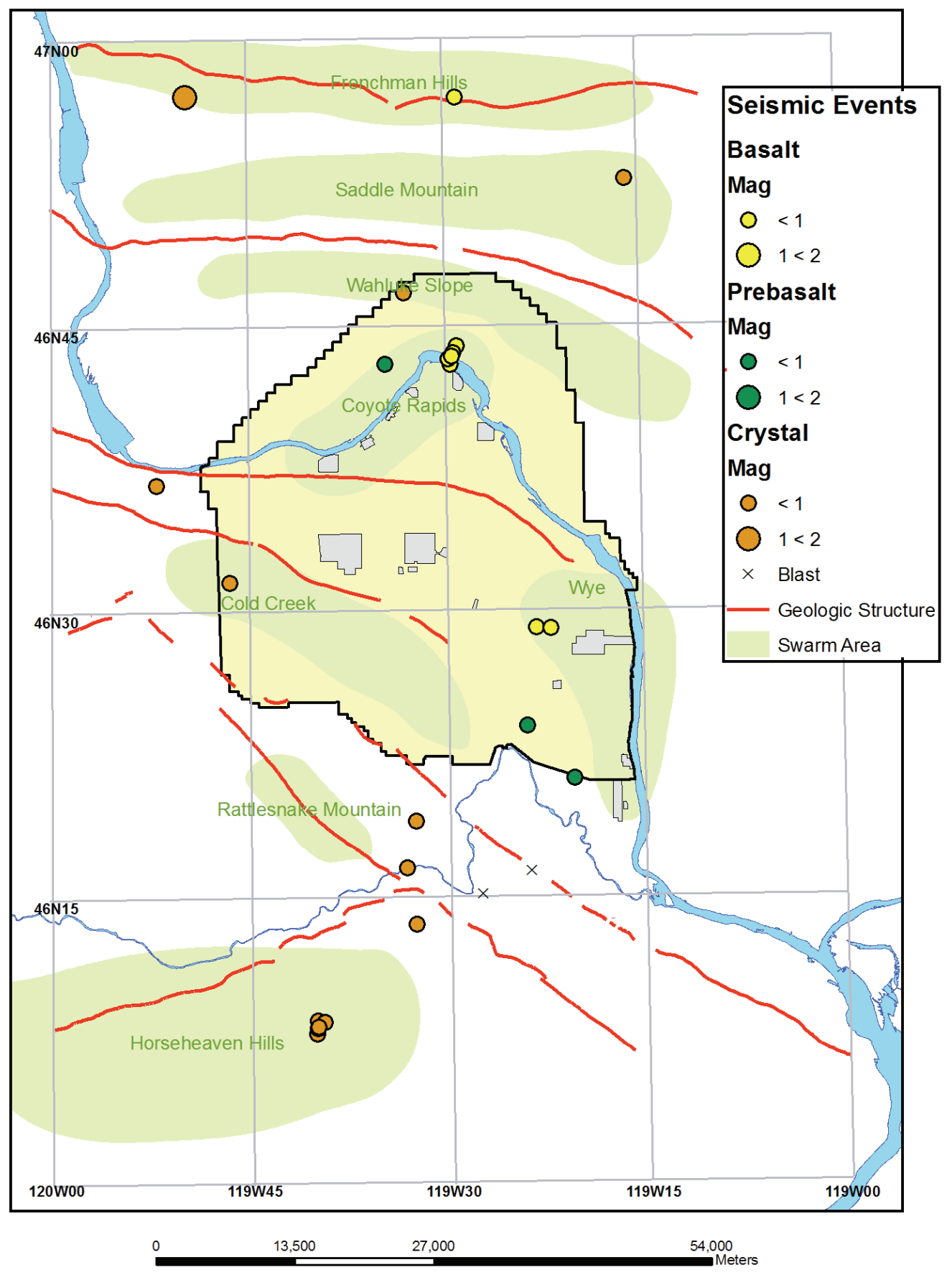

Figure 4.4. Fourth-Quarter FY 2007 Earthquakes Recorded in the Hanford Monitoring Area (July 2006 through September 2007)

\section{Saddle Mountains Swarm Area}

On July 26, 2007, a minor earthquake was recorded at depth $13.3 \mathrm{~km}$ within the crystalline basement. 


\section{Wahluke Slope Swarm Area}

On September 5, 2007, a minor earthquake was recorded at depth $12.5 \mathrm{~km}$ within the crystalline basement.

\section{Coyote Rapids Swarm Area}

Seven minor events were recorded during the fourth quarter of FY 2007. Six events (July 30, August 3, August 19, August 20, September 2, and September 20) with estimated depths in the 1-5 km range were classified within the CBRG. This determination was made due to the proximity of epicenters and the uncertainty associated with depth estimates. Another minor event was recorded on September 7 , 2007, and located approximately $6 \mathrm{~km}$ west of the six-event cluster and classified within the pre-basalt sediments.

\section{Wye Swarm Area}

Two minor events were recorded nearly simultaneously on July 1, 2007, with epicenters within $1500 \mathrm{~m}$ of each other. The first event $\left(0.5 \mathrm{M}_{\mathrm{c}}\right)$ with estimated depth $0.05 \mathrm{~km}$ was located in the CBRG. The second event $\left(0.0 \mathrm{M}_{\mathrm{c}}\right)$ with estimated depth $7.41 \mathrm{~km}$ was considered to be the same event as the first and categorized within the CBRG.

\section{Cold Creek Swarm Area}

One minor event was recorded on September 17, 2007 at depth $20.22 \mathrm{~km}$ within the crystalline basement.

\section{Horse Heavens Swarm Area}

Five minor events were recorded nearly simultaneously on September 20, 2007, with depths of approximately $10 \mathrm{~km}$ within the crystalline basement (Figure 4.4).

\subsubsection{Random or Floating Events}

During the fourth quarter of FY 2007, six minor seismic events were classified as random events. Four of these events occurred deep within the crystalline basement (August 18, August 31, September 7, and September 26) at depths ranging from 8-17 km. Three of these events were located south of the Hanford Site near the Yakima River, and one was located west of the Hanford Site near the Columbia River. Two events occurred within the pre-basalt sediments (August 28 and August 31) near the southern boundary of the Hanford Site at depths of approximately $4 \mathrm{~km}$. 


\subsection{Strong Motion Accelerometer Operations - FY 2007 Triggers}

The Hanford SMA network has been in continuous operation since November 20, 1998. Initially, the threshold used in the SMA network was $0.1 \% \mathrm{~g}$. In 2006, the trigger threshold was reduced to $0.02 \% \mathrm{~g}$ when new instruments with greater storage capacity were installed, allowing more noise triggers to be saved without exceeding disk capacity.

The Hanford SMA network was triggered by the $2.0 \mathrm{M}_{\mathrm{c}}$ seismic event that occurred on April 16, 2007. That event was recorded on the 300 Area and the 400 Area SMAs. Data shown in Figures 5.1 and 5.2 were plotted from event files downloaded from the SMA units.

Figure 5.1 shows the time history of ground acceleration recorded at the 300 Area SMA station. Converting the voltages shown in Figure 5.1 to ground acceleration, the maximum vertical acceleration was $0.07 \% \mathrm{~g}$ and the maximum horizontal acceleration was $0.05 \% \mathrm{~g}$. At the 400 Area SMA station, shown in Figure 5.2, the maximum vertical acceleration was $0.25 \% \mathrm{~g}$ and the maximum horizontal acceleration was $0.23 \% \mathrm{~g}$. Accelerations at the 400 Area SMA $(5.2 \mathrm{~km}$ distant from the event) are three to five times larger than at the 300 Area SMA (13.5 km from the event). These are the second recordings of a small local earthquake on the SMA network; the 400 Area SMA was triggered by a magnitude 1.5 microearthquake April 17, 2006. Previous earthquake triggers on the SMA network were from the magnitude 6.8 Nisqually earthquake in western Washington (February 28, 2001) and the magnitude 7.9 Denali earthquake in Alaska (November 3, 2002).

The upgrade of the SMA units in FY 2006 provides for reduced trigger levels $(0.02 \% \mathrm{~g}$ compared to $0.10 \%$ to $0.20 \%$ g previously) that allowed the 300 Area SMA to trigger. The 400 Area SMA would have triggered at the higher $\mathrm{g}$ threshold at this closer location. The reportable action level of $2 \% \mathrm{~g}$ for Hanford facilities is approximately eight times larger than the peak accelerations observed at the 400 Area, and no action was required. However, this earthquake did do damage to the vibration-sensitive optical systems at the Laser Interferometric Gravitational Wave Observatory (LIGO). 


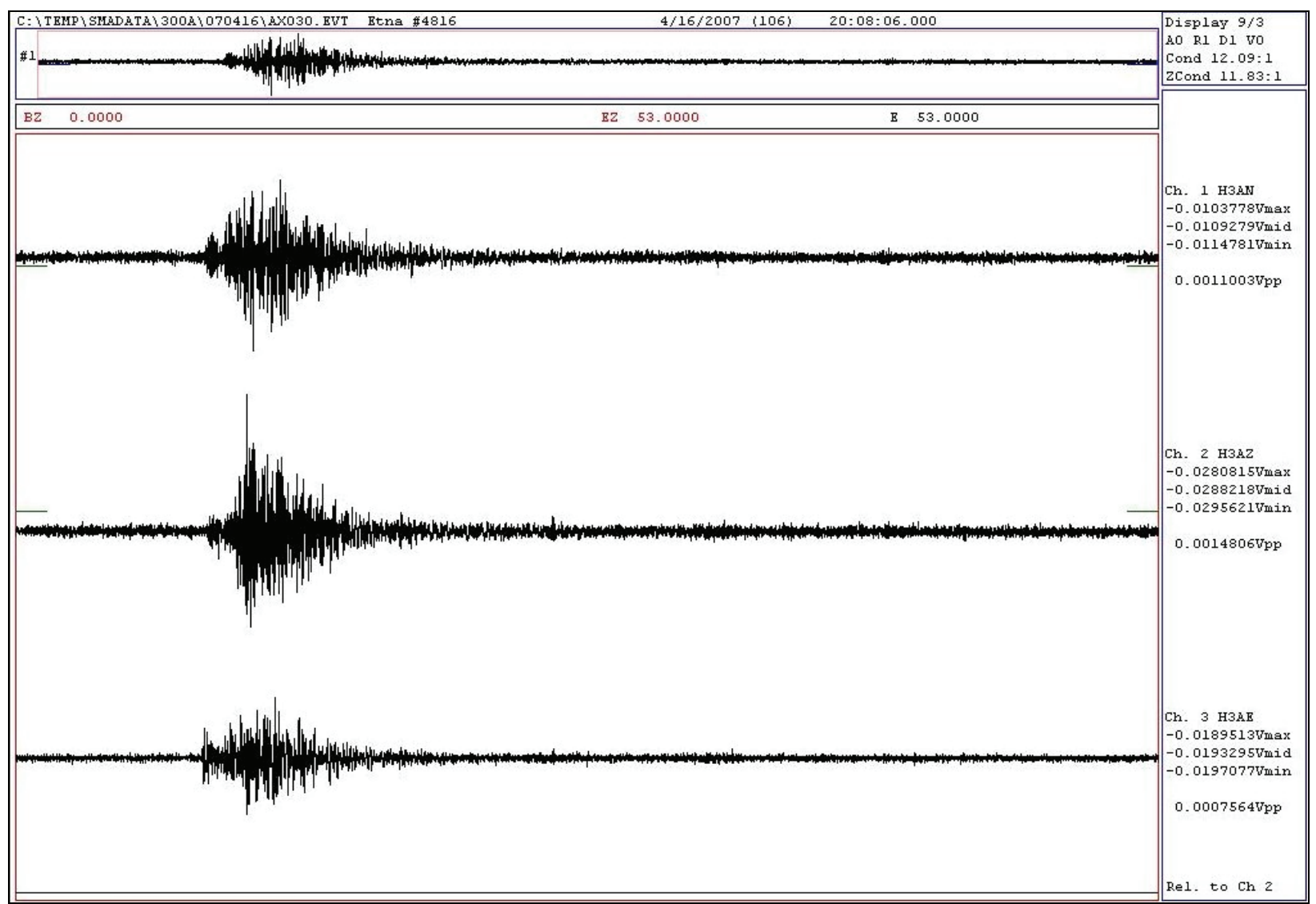

Figure 5.1. April 16, 2007, Microearthquake Acceleration Time Histories at 300 Area SMA 


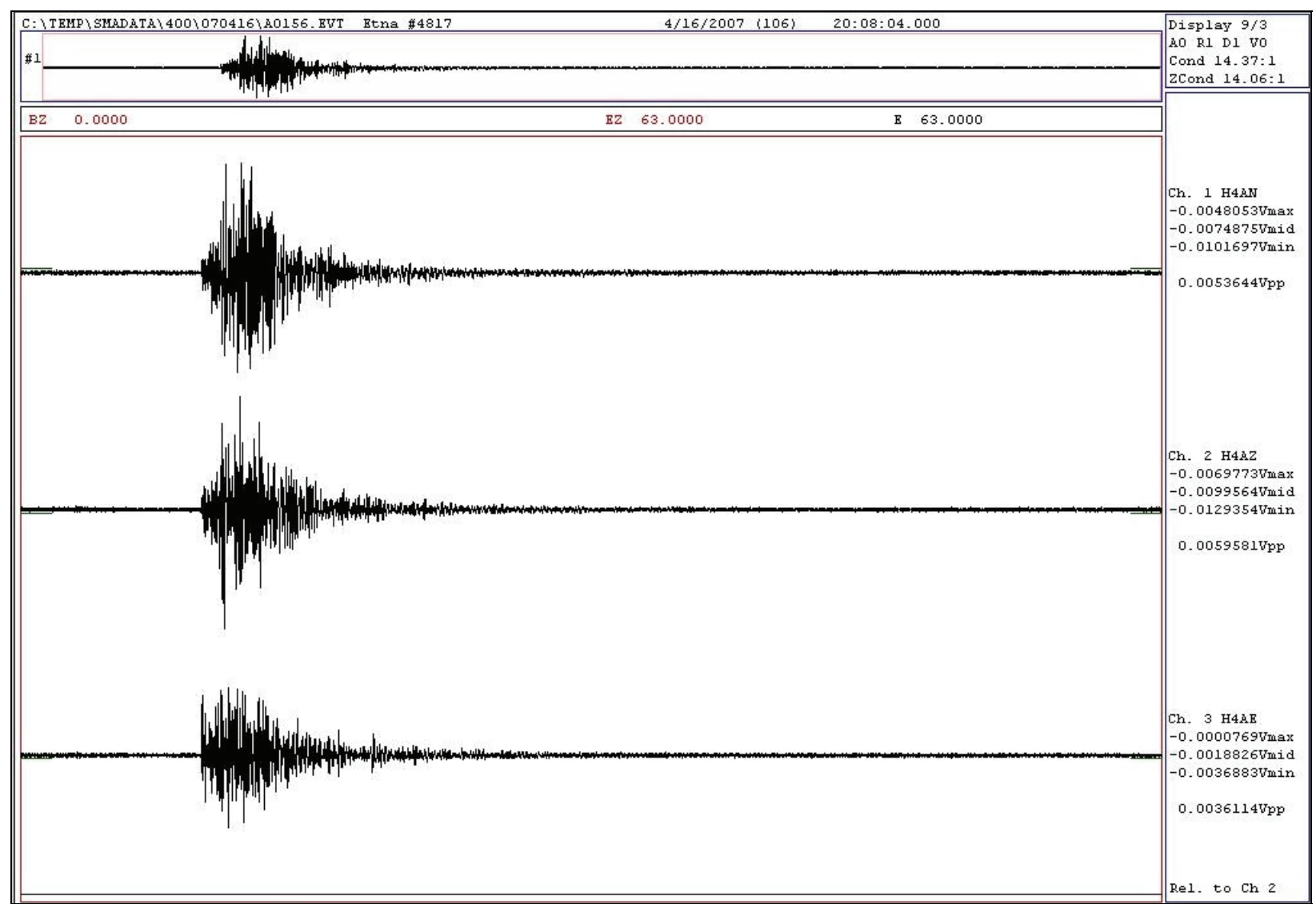

Figure 5.2. April 16, 2007, Microearthquake Acceleration Time Histories at 400 Area SMA 


\subsection{Capabilities in the Event of a Significant Earthquake}

The SMA network was designed to provide ground motion data in areas at the Hanford Site that have high densities of people and/or facilities containing hazardous materials, to ensure that the Hanford Site is in compliance with DOE Order 420.1A, "Facility Safety." The network also allows the HSAP to support Hanford Site emergency services organizations in complying with DOE Order G 420.1-1, Section 4.7, "Emergency Preparedness and Emergency Communications," by providing area ground motion data in the event of an earthquake on the Hanford Site. This section summarizes the capabilities of the HSAP in the event of an earthquake at Hanford.

Historically, only a few facilities at the Hanford Site had instruments to provide data on peak ground accelerations or any type of ground motion. The current SMA instruments were located so that if an earthquake occurred, ground motion data would be readily available to assess the damage at the 100-K Area, the 200 East and West Areas, and the 300 and 400 Area facilities, which have the greatest concentration of people and also contain hazardous materials (Moore and Reidel 1996).

Many facilities at the Hanford Site have undergone various degrees of seismic analysis, either during design or during requalification. Although the seismic design of a building may be known, when an earthquake is "felt" in a facility on the Hanford Site, a determination must be made as to the extent of damage before it can be reoccupied and the systems restarted. A "felt" earthquake may not cause any significant damage to a building but, without adequate characterization of the ground motion, initial determination of the building's possibility of having damage may be impossible.

In the event of a major regional earthquake such as the 2001 Nisqually event, building managers, emergency directors, and engineers can obtain ground motion data recorded by the SMA network from the HSAP in the Sigma V Building. This is done through the Hanford Site Emergency Services organization. Normal hours of operation for the HSAP are between 6 a.m. and 4:30 p.m., Monday through Friday. If a SMA is triggered, the HSAP will download events that were recorded and determine the peak ground accelerations. This information is then passed on to Hanford Site Emergency Services personnel where the facility engineers can use the data to determine if the ground motion exceeded, is equal to, or is less than the building design. This, along with assessments from trained engineers, allows the facility manager to make a rapid and cost-effective determination on whether a building is safe to reoccupy or should not be used until it has been inspected in more detail. Buildings that have designs exceeding the recorded ground motion could be put back into service very quickly; buildings with designs that are very close to or less than measured ground motion could be given priority for onsite damage inspections. 


\subsection{References}

Campbell NP. 1989. "Structural and Stratigraphic Interpretation of Rocks under the Yakima Fold Belt, Columbia Basin, Based on Recent Surface Mapping and Well Data." In Volcanism and Tectonism in the Columbia River Flood-Basalt Province, SP Reidel and PR Hooper (eds), Special Paper 239, pp. 209-222. Geological Society of America, Boulder, Colorado.

Crosson RS. 1972. "Small Earthquakes, Structure and Tectonics of the Puget Sound Region." Bulletin of the Seismological Society of America 62(5):1133-1171.

DOE. 1988. Site Characterization Plan for the Reference Location, Hanford, Washington-

Consultation Draft. DOE/RW-0164, Vol. 1, U.S. Department of Energy, Washington, D.C.

DOE Order 420.1B, Chapter IV, Section 3.d. "Seismic Detection.” U.S. Department of Energy, Washington, D.C.

DOE Order G 420.1-1, Section 4.7. "Emergency Preparedness and Emergency Communications." U.S. Department of Energy, Washington, D.C.

Fenneman NM. 1931. Physiography of Western United States. McGraw-Hill Book Company, Inc., New York.

Geomatrix. 1996. Probabilistic Seismic Hazard Analysis, DOE Hanford Site, Washington. WHC-SDW236A-TI-002, Rev. 1, Westinghouse Hanford Company, Richland, Washington.

Moore C and SP Reidel. 1996. Hanford Site Seismic Monitoring Instrumentation Plan. WHC-SD-GNER-30036, Westinghouse Hanford Company, Richland, Washington.

Reidel SP and KR Fecht. 1994a. Geologic Map of the Richland 1:100,000 Quadrangle, Washington. Open File Report 94-8, Division of Geology and Earth Resources, Washington State Department of Natural Resources, Olympia.

Reidel SP and KR Fecht. 1994b. Geologic Map of the Priest Rapids 1:100,000 Quadrangle, Washington. Open File Report 94-13, Division of Geology and Earth Resources, Washington State Department of Natural Resources, Olympia.

Reidel SP, NP Campbell, KR Fecht, and KA Lindsey. 1994. "Late Cenozoic Structure and Stratigraphy of South-Central Washington." In Regional Geology of Washington State, E Cheney and R Lasmanis (eds), Bulletin 80, pp. 159-180. Division of Geology and Earth Resources, Washington State Department of Natural Resources, Olympia.

Reidel SP, KR Fecht, MC Hagood, and TL Tolan. 1989. "Geologic Development of the Central Columbia Plateau." In Volcanism and Tectonism in the Columbia River Flood-Basalt Province, SP Reidel and PR Hooper (eds), Special Paper 239, pp. 247-264. Geological Society of America, Boulder, Colorado.

Richter CF. 1958. Elementary Seismology. W. H. Freeman \& Company, San Francisco, California. 
Rohay AC, DW Glover, and SD Malone. 1985. Time-Term Analysis of Upper Crustal Structure in the Columbia Basin, Washington. RHO-BW-SA-435 P, Rockwell Hanford Operations, Richland, Washington.

Rohay AC, MD Sweeney, SP Reidel, DC Hartshorn, and RE Clayton. 2007a. First Quarter Seismic Report for Fiscal Year 2007. PNNL-16480, Pacific Northwest National Laboratory, Richland, Washington.

Rohay AC, MD Sweeney, SP Reidel, DC Hartshorn, and RE Clayton. 2007b. Second Quarter Seismic Report for Fiscal Year 2007. PNNL-16689, Pacific Northwest National Laboratory, Richland, Washington.

Rohay AC, MD Sweeney, DC Hartshorn, RE Clayton, and JL Devary. 2007c. Third Quarter Seismic Report for Fiscal Year 2007. PNNL-16872, Pacific Northwest National Laboratory, Richland, Washington. 


\section{Distribution}

No. of

\section{Copies}

\section{OFFSITE}

Administrator

Kennewick General Hospital

P.O. Box 6128

Kennewick, WA 99336

R. Carson

Department of Geology

Whitman College

345 Bayer Avenue

Walla Walla, WA 99362

T. Conrads

Parsons Constructors, Inc.

3005 E. Ainsworth Street

Pasco, WA 99301

G. Crawford

Washington Emergency Management

Division

Building 20, M/S: TA-20

Camp Murray, WA 98430-5122

Idaho Geological Survey

Morrill Hall

University of Idaho

P.O. Box 443014

Moscow, ID 83844-3014

J. Kimball

Defense Nuclear Facilities Safety Board 625 Indiana Avenue NW, Suite 700

Washington, DC 20004
No. of

Copies

S. Lilligren

Nez Perce Tribe

P.O. Box 365

Lapwai, ID 83540

J. Litehiser

Bechtel National, Inc.

P.O. Box 193965

San Francisco, CA 94119-3965

2 Oregon Department of Geology and Mineral Industries

Suite 965, 800 NE Oregon Street \#28

Portland, OR 97232

ATTN: Library

I. Madin

N. Rasmussen

3140 Ravenshoe Drive

Las Vegas, NV 89134

S. P. Reidel

WSU Tri-Cities

2710 University Drive

Richland, WA 99354

P. Rizzo

105 Mall Boulevard

Monroeville, PA 15146

M. Stickney

Montana Tech University

Earthquake Studies Office

Butte, MT 59701

A. Tallman

1940 Quail Court

West Richland, WA 99353 
No. of

Copies

5 University of Washington

Geophysics Program

P.O. Box 351650

Seattle, WA 98195-1650

ATTN: P. Bodin

R. Ludwin

S. Malone

R. Steele

J. Vidale

2 University of Washington

U.S. Geological Survey

P.O. Box 351650

Seattle, WA 98195-1650

ATTN: C. Weaver

T. Yelin

U.S. Fish and Wildlife Service

3250 Port of Benton Boulevard

Richland, WA 99352

U.S. Geological Survey

Mail Stop 977

345 Middlefield Road

Menlo Park, CA 94025

ATTN: T. Brocher

2 Washington Division of Geology and Earth

Resources

P.O. Box 47007

Olympia, WA 98504-7007

ATTN: Library

T. Walsh

Washington State University

Department of Geology

P.O. Box 643420

Pullman, WA 99164-2812

R. Whale

Shell E\&P

200 N. Dairy Ashford

Houston, TX 77079
No. of

Copies

I. G. Wong

URS Corporation

1333 Broadway, Suite 800

Oakland, CA 94612

J. Zollweg

Boise State University

Department of Geosciences

Boise, ID 83725

\section{ONSITE}

7 DOE Richland Operations Office

B. L. Charboneau

A6-33

K. L. Flynn

A6-35

T. Y. Hale

A7-90

R. D. Hildebrand

A6-38

M. R. Moreno

H6-60

J. G. Morse

A6-38

Y. T. Sherman

A6-35

DOE Office of River Protection

L. F. Miller

H6-60

Bechtel Hanford, Inc.

K. R. Fecht

H9-01

5 CH2M HILL Hanford Group, Inc.

F. J. Anderson

H6-03

D. D. Bachland

S5-15

J. R. Freeman-Pollard

R3-77

D. T. Heimberger

S5-25

F. M. Mann

H6-03

\section{Duratek Federal Services Hanford}

R. T. Wilde

H8-44 
No. of

Copies

10 Fluor Hanford, Inc.

M. E. Brown

D. A. Conners

J. T. Curtis

S. A. Fargo

S. M. Faulk

B. H. Ford

D. G. Horton

T. P. Morales

M. I. Wood

M. T. York

Stoller

R. McCain
G5-51

T3-28

B3-15

H8-60

A3-05

E6-35

E6-35

A3-05

H8-44

N2-02
No. of

Copies

Washington State Department of Ecology

$\begin{array}{ll}\text { J. Caggiano H0-57 } & \text { H }\end{array}$

18 Pacific Northwest National Laboratory

R. E. Clayton K6-75

J. L. Devary (5) K6-96

D. C. Hartshorn K6-75

P. E. Moore J2-09

B. E. Opitz K6-75

A. C. Rohay K6-75

H. T. Schaef K6-81

M. D. Sweeney (5) K6-75

Hanford Technical Library (2) P8-55 